\title{
ADVANCED SECONDARY RECOVERY PROJECT FOR THE SOONER "D" SAND UNIT, WELD COUNTY, COLORADO COOPERATIVE AGREEMENT DE-FC22-93BC14954
}

\section{FINAL REPORT}

Report Date:

July 1996

Award Date:

October 21, 1992

Completion Date:

November 30, 1995

Project Manager:

Terry J, Cammon

Diversified Operating Corporation

Principal Investigator:

Mark A. Sippel

Mark Sippel Engineering, Inc.

DOE Project Officer:

Edith Allison

Bartlesville Project Office

DOE Contract Officer:

David Hunter

Pittsburgh Energy Technology Center

Prepared by

Diversified Operating Corp.

1675 Larimer Street, Suite 400

Denver, Colorado 80202 


\section{ADVANCED SECONDARY RECOVERY PROJECT FOR THE SOONER “D” SAND UNIT,

\author{
WELD COUNTY, COLORADO \\ COOPERATIVE AGREEMENT DE-FC22-93BC14954
}

Disclaimer

This report was prepared as an account of work sponsored by an agency of the United States Government. Neither the United States Government nor any agency thereof, nor their employees, makes any warranty, expressed or implied, or assumes any legal liability or responsibility for the accuracy, completeness, or usefulness of any information, apparatus, product, or process disclosed or represented that its use would not infringe privately owned rights. Reference herein to any specific commercial product, process, or service by trade name, trademark, manufacturer, or otherwise does not necessarily constitute or imply its endorsement, recommendation, or favoring by the United States Government or any agency thereof. The views and opinions of authors expressed herein do not necessarily state or reflect those of the United States Government or any agency thereof. 


\title{
ADVANCED SECONDARY RECOVERY PROJECT FOR THE SOONER “D” SAND UNIT,
}

\author{
WELD COUNTY, COLORADO \\ COOPERATIVE AGREEMENT DE-FC22-93BC14954
}

\begin{abstract}
The objective of this project is to increase production from the Cretaceous D Sandstone in the Denver-Julesburg (D-J) Basin through geologically targeted infill drilling and improved reservoir management of waterflood operations. This project involves multidisciplinary reservoir characterization using high-density 3D seismic, detailed stratigraphy and reservoir simulation studies. Infill drilling, water-injection conversion and re-completing some wells to add short-radius laterals will be based on the results of the reservoir characterization studies. Production response will be evaluated using reservoir simulation and production tests. Technology transfer will utilize workshops, presentations and technical papers which will emphasize the economic advantages of implementing the demonstrated technologies. The success of this project and effective technology transfer should prompt-reappraisal of older waterflood projects and implementation of new projects in oil provinces such as the $\mathrm{D}-\mathrm{J}$ Basin.
\end{abstract}


ADVANCED SECONDARY RECOVERY PROJECT FOR THE SOONER “D” SAND UNIT,

\author{
WELD COUNTY, COLORADO \\ COOPERATIVE AGREEMENT DE-FC22-93BC14954
}

Section

Table of Contents

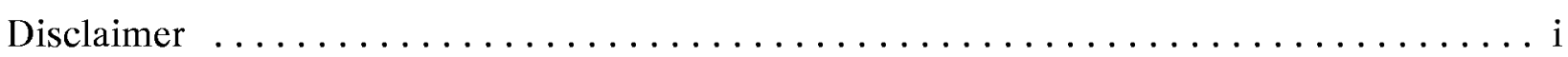

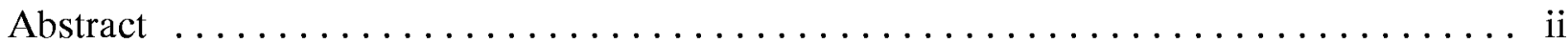

Table of Contents $\ldots \ldots \ldots \ldots \ldots \ldots \ldots \ldots \ldots \ldots \ldots \ldots \ldots \ldots \ldots \ldots \ldots \ldots \ldots$ iii

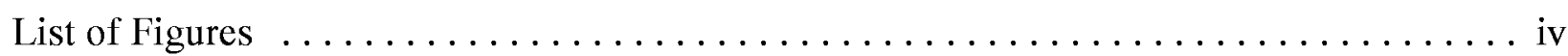

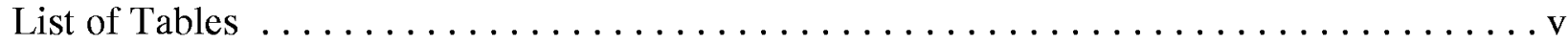

Executive Summary ................................... vi

Background of Exploration and Waterflooding for the D Sandstone $\ldots \ldots \ldots \ldots \ldots$ I-1

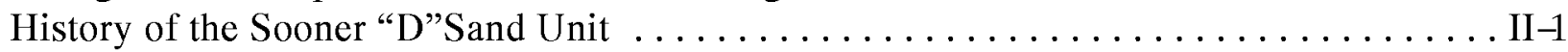

Geology of the Sooner "D" Sand Unit and Adjacent Area .................... III-1

Petrographical Analysis of the D Sandstone .......................... IV-1

Core and Electrical Log Descriptions of the D Sandstone ................ V-1

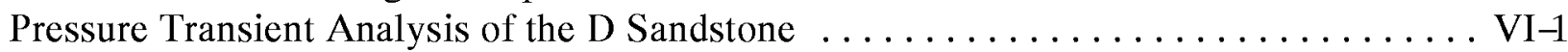

Seismic Characterizations of the D Sandstone $\ldots \ldots \ldots \ldots \ldots \ldots \ldots \ldots \ldots \ldots$ VII -1

Reservoir Compartments .................................. VIII-1

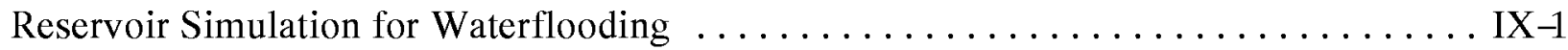

Targeted Infill Drilling and Economics $\ldots \ldots \ldots \ldots \ldots \ldots \ldots \ldots \ldots \ldots \ldots \ldots \ldots \ldots \ldots \ldots$

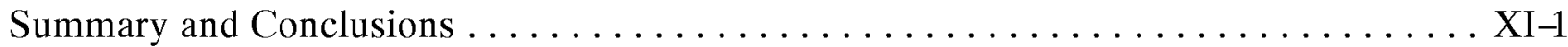


ADVANCED SECONDARY RECOVERY PROJECT FOR THE SOONER "D” SAND UNIT,

\author{
WELD COUNTY, COLORADO \\ COOPERATIVE AGREEMENT DE-FC22-93BC14954
}

Figure

List of Figures

Figure I-1

Figure I-2

Figure II-1

Figure II-2

Figure III-1

Figure III-2

Figure III-3

Figure III-4

Figure III-5

Figure III-6

Figure III-7

Figure III-8

Figure III-9

Figure IV-1

Figure IV-2

Figure IV-3

Figure IV-4

Figure V-1

Figure V-2

Figure VII-1

Figure VII-2

Figure VII-3

Figure VII-4

Figure VII-5

Figure VII-6

Figure VII-7

Figure VII-8

Figure VII 9

Figure VIII-1

Figure VIII-2

Figure VIII-3

Figure VIII-4

Figure IX-1

Figure IX-2

Figure IX-3

Figure IX-4

Figure $X-1$

Figure $X-2$
Limits of Denver Basin and D Sandstone Play. ............. I-5

Denver Basin and D Sandstone Fields in Eastern Colorado ......... I-6

Net Pay Interpretation of the D Sandstone at the Sooner Unit in 1988. . . . II-2

Production History from the Sooner Unit "D" Sand Unit . . . . . . . . II-3

Location of Sooner Unit and D Sandstone Fields in Eastern Colorado ... III-5

Structure Map of D Sandstone ...................... III-6

Type Log of D Sandstone and Adjacent Llithology ........... III-7

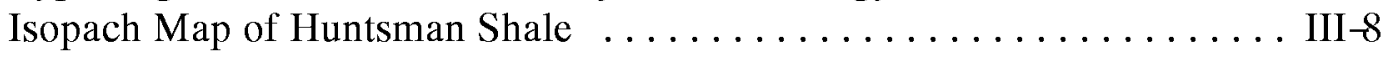

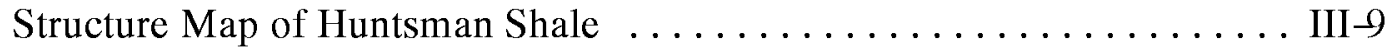

Depositional Block Ddiagram for D Sandstone $\ldots \ldots \ldots \ldots \ldots \ldots$ III-10

Isopach Map of 'X' Bentonite to Mowry . . . . . . . . . . . . III-11

Log Cross-Section with Faulting . . . . . . . . . . . .

Cross-Section of Thick Valley-Fill $\ldots \ldots \ldots \ldots \ldots \ldots \ldots \ldots \ldots \ldots \ldots \ldots \ldots \ldots$ III-13

Core Log of D Sandstone from SU $7-21 \ldots \ldots \ldots \ldots \ldots \ldots \ldots \ldots \ldots \ldots \ldots \ldots$

Density Log from SU $7-21 \ldots \ldots \ldots \ldots \ldots \ldots \ldots \ldots \ldots \ldots \ldots \ldots \ldots$

Density Log from SU $21-14-1 \ldots \ldots \ldots \ldots \ldots \ldots \ldots \ldots \ldots \ldots \ldots$

Stratigraphic Comparison of SU $21-14-1$ and $7-21 \ldots \ldots \ldots \ldots \ldots$ IV -10

Porosity Permeability Cross-Plot from D Sandstone Cores ........ V-3

Permeability Distribution from D Sandstone Cores $\ldots \ldots \ldots \ldots \ldots . V-4$

Seismic Section from Sooner 3D Data Volume $\ldots \ldots \ldots \ldots \ldots \ldots$ VII-10

Synthetic Seismogram Cross-Section . ................. VII-11

Stratigraphic West-East Cross-Section at the Sooner Unit . . . . . . VII-12

Seismic Amplitude of the D Sandstone at the Sooner Unit . . . . . . . VII-13

Seismic Isochron of the D Sandstone at the Sooner Unit . . . . . . . VII-14

Prediction of Gross Thickness from Seismic Attributes .......... VII-15

Prediction of Net-Pay Thickness from Seismic Attributes ......... VII-16

Prediction of Hydrocarbon-Feet from Seismic Attributes . . . . . . . . VII-17

Net-Pay Map of the Sooner Unit D Sandstone in $1988 \ldots \ldots \ldots \ldots$ VII-18

Schematic of Compartments in D Sandstone Reservoirs $\ldots \ldots \ldots \ldots$ VIII -3

Pre-Unitization Map of Reservoir Using Net Thickness . . . . . . . VIII-4

Map of Functional Reservoir Compartments . . . . . . . . . VIII-5

3D seismic Attribute Map of Huntsman Shale ............. VIII-6

Functional Reservoir Compartments at Sooner Unit ............. IX-7

3D Seismic Attribute Map of Huntsman Shale .............. IX-8

Example of Single-Well History Matching . . . . . . . . . . . . . IX -9

History Match of Composite Sooner Unit ................ IX-10

Map of Drilling Activity During the Project ............... X-5

Map of Hydrocarbon-Feet from Siesmic-Attribute Correlations $\ldots \ldots$ X-6 
Figure $\mathrm{X}-3 \quad$ Map-View of Functional Reservoir Compartments $\ldots \ldots \ldots \ldots \ldots$ 


\title{
ADVANCED SECONDARY RECOVERY PROJECT FOR THE SOONER “D” SAND UNIT,
}

\author{
WELD COUNTY, COLORADO \\ COOPERATIVE AGREEMENT DE-FC22-93BC14954
}

List of Tables

Table

Page

Table I-1 Recovery by Waterflood from D Sandstone Fields Near the Sooner Unit. . . I-3

Table IV-1 Composition of D Sandstone from Thin-Section Analysis . . . . . . . IV-4

Table IV-2 Grain Size for D Sandstone from Thin-Section Samples . . . . . . . . . IV-4

Table IV-3 D Sandstone Petrographic Descriptions from SU 21-14-1 . . . . . . . IV-5

Table V-1 Permeability Data from D Sandstone Cores in the Sooner Unit Area. .... V-1

Table V-2 Summary of Log Calculations in the D Sandstone at the Sooner Unit . . . V-2

Table VI-1 Summary of Pressure Fall-off Analysis from Water Injection Wells ...... VI-1

Table VII-1 Processing Flow Used for Sooner 3D Seisimic Data . . . . . . . . . . VII-8

Table VII-2 Correlation Coefficients of Seismic and Electrical Log Data . . . . . . . VII -9

Table IX-1 Reservoir Properties Used for Simulation . . . . . . . . . . . . . IX-2

Table IX-2 Results from History Matching by Well . . . . . . . . . . . . IX-4

Table IX-3 Results from History Matching Composite Production . . . . . . . . IX5

Table IX-4 Economic Value of Various Thicknesses in a 40-acre, 2-Spot Waterflood Pattern Before Capital Expenditures . . . . . . . . . IX 6

Table X-1 Economic Model for Comparison of Targeted and Blanket Infill Drilling . X-4 


\title{
ADVANCED SECONDARY RECOVERY PROJECT FOR THE SOONER “D” SAND UNIT,
}

\author{
WELD COUNTY, COLORADO \\ COOPERATIVE AGREEMENT DE-FC22-93BC14954
}

Executive Summary

Production and Reserves

The oil producing rate at the Sooner Unit was increased nearly 200 bopd above preproject projected trends. The projected ultimate developed reserves were increased from $1,556,000 \mathrm{bbl}$ to $1,861,000 \mathrm{bbl}$. These production increases were the result of realignment of injection-production patterns and the drilling of one injection well and one production well. The original-oil-in-place (OOIP) calculated for the Sooner Unit were increased from $5,900,000 \mathrm{bbl}$ to $6,900,000 \mathrm{bbl}$. The increase in OOIP are the result of seismic mapping which was integrated with geological and engineering studies. The methodologies and development plan which evolved during the project lead to projections of 2,252,000 bbl (33 percent of OOIP) ultimate recovery after drilling of an additional five wells.

Seismic Modeling

Detailed synthetic seismic modeling was performed to determine resulting seismic signature and seismic frequency content necessary to resolve the internal stratigraphic architecture within the D Sandstone interval and to confirm the mapping and interpretation methodologies from earlier work during the project.

Seismic Attribute Correlation

Correlations of seismic attributes were made with petrophysical properties from electrical log data. It was found that direct attributes of the D Sandstone interval were inconsistent with reservoir development. Combination of attributes from the D Sandstone and adjacent temporal horizons through multiple-tinear regression resulted in maps which were more consistent with geological and engineering interpretations. It is concluded that adjacent non-reservoir rock can provide important indicators of positive or negative development in adjacent reservoir rock.

\section{Horizontal Completions}

Attempts to drill a horizontal extension in a centrally located injection well were unsuccessful. Mechanical difficulties were encountered in the first attempt which utilized technology to drill an ultra-short radius curve with articulated drill collars and angled bottomhole assembly. The second attempt utilized a short-radius curve with a downhole mud-motor and steering assembly. A collapsing shale section above the target formation prevented completion of the lateral extension. A lithological barrier was penetrated during the second drilling attempt which confirms the objective and purpose of the horizontal extension. 


\section{Vertical Wells}

Two conventional, vertical wells were drilled based on integrated studies. One well was an injection well and the other was a production well. The injection well encountered a thick gross $(55 \mathrm{ft})$ section of D Sandstone but had only $6 \mathrm{ft}$ of net reservoir thickness. The producing well location was based on seismic attribute correlations. It encountered $26 \mathrm{ft}$ of net reservoir thickness and was completed with a producing rate of over $200 \mathrm{bopd}$.

\section{Petrography}

Descriptions were made from whole and sidewall cores. Permeability ranges from 1 md to $100 \mathrm{md}$ with a geometric-mean permeability of $21 \mathrm{md}$. Average porosity is 11.5 percent. Sidewall cores were taken from the SU 21-14-1 well. Petrographical studies and thin sections were made of these core samples. The study indicates that poor porosity and permeability development are primarily related to deposition. Clays and cements were found to be indicative of different facies. Low-stand facies are characterized by kaolinite and feldspar. Abundance of calcite cement and chlorite clay suggest a transgressive setting with rising marine water. Low porosity and permeability rock results from fine laminations of clay and silty material.

\section{Pressure Tests}

Pressure tests taken during the project consisted of static shut-in measurements and transient surveys for injection and production wells. Pressure falloff tests were performed on three water-injection wells. Pressure buildup tests were taken from four producing wells.

\section{Realign Injection-Production}

Four wells were converted from either production to injection or vice-versa in order to realign injection patterns which are better suited to the understanding of functional reservoir compartments. Reservoir management utilizing balancing injection with withdrawals of fluids and gas by compartments had a positive result. Gas recycling was found to limit waterinjection and was terminated.

Inter-well Tracers

Inter-well tracers were tested at three injection wells. Sodium bromide was used as the tracer material. Results were inconclusive.

\section{Reservoir Simulation}

Reservoir simulation was performed for two-spot situations to calculate recoverable oil in small, two-well compartments. 
Technology Transfer

An oral presentation was made at the regional section meeting of AAPG in Reno, NV in July, 1995. The talk presented the case history of drilling a horizontal well at the Sooner Unit.

A workshop presentation was made on November 17, 1995 in Denver with the Rocky Mountain regional Petroleum Technology Transfer Council (PTTC). The Sooner project was one of three characterization studies presented from Eastern Colorado oil fields.

The project was presented on tour in six cities with the PTTC-BDM U.S. Department of Energy Class I traveling workshop during January and February, 1996.

All reservoir characterization data were donated to the Colorado School of Mines for use under the direction of Robert Thompson, John Curtis and Tom Davis. This data set includes electrical logs, production, pressure transient tests and 3D seismic. The data have been used in under-graduate classes and in graduate studies.

The Sooner 3D seismic survey was donated to the Rocky Mountain PTTC under the direction of Roger Slatt for use in the computer-technology demonstration lab. 


\title{
ADVANCED SECONDARY RECOVERY PROJECT FOR THE SOONER “D” SAND UNIT,
}

\author{
WELD COUNTY, COLORADO \\ COOPERATIVE AGREEMENT DE-FC22-93BC14954
}

Background of Exploration and Waterflooding for the D Sandstone

Exploration

The D Sandstone play in the Denver Basin encompasses northeast Colorado and southwest Nebraska (Fig. I-1). The D Sandstone is a subsurface member of the Dakota Group and is early Late Cretaceous age (Haun 1963). About 160 (42 percent) of the D Sandstone reservoirs in Colorado were abandoned or shut-in as of 1992 (Hemborg 1993). Although the D Sandstone may be considered a mature play, significant discoveries are still possible as shown by the discovery of Sooner Field in 1985 and Lilli Field in 1987, both in T. 8 N, R. 58 W., Weld County, Colorado.

The west side of the Denver Basin was the second area in the United States to produce oil from drilled wells. The early exploration was based on random wildcatting for fractured shale zones near oil seeps from 1862 through 1922. After 1920, exploration was based on surface geological surveys for anticlinal structures on the west side of the basin near the front range of the Rocky Mountains. Development of the east flank of the basin was slower than the west flank because of low, unreliable surface dips and blanket Tertiary gravel beds.

A 1930 wildcat discovery (sec. 24, T. 6 N., R. 61 W.) on a gentle surface anticline on the east flank of the basin in east Weld County, Colorado established the initial production from the D Sandstone and the first production from any reservoir on the east flank of the basin (Lavington 1941). This well, the Platte Valley Petroleum Corporation Patterson No. 1, initially flowed 184 barrels of oil a day from a depth of $6661 \mathrm{ft}$. This D field was named Greasewood (Fig. I-2). The operators who developed the field believed trapping in the Greasewood was a stratigraphic-structural combination. The discovery of Greasewood Field resulted in some additional nearby wildeat drilling. Interest in the Greasewood area and the east flank of the Denver Basin subsided quickly because of 1) lack of further discoveries, 2) the achievement of commercial production in only two of eight Greasewood Field development wells, 3) realization that surface structure did not mirror D Sandstone reservoir structure, and 4) erratic distribution of the D Sandstone in Greasewood Field (Rountree 1984).

After 1949, seismic exploration resulted in finding D Sandstone production on subsurface areas with structural nosing and anticlinal closures. In August 1949, the Ohio Oil Company completed a 225 barrel per day oil discovery from the D Sandstone near Gurley, Cheyenne County, Nebraska. This discovery, Egging No. 1, precipitated a decade and a half of active exploration on the east flank of the basin which caused the discovery of most Nebraska and Colorado D Sandstone reservoirs (Volk 1972). Many early D Sandstone fields were discovered from seismic leads, but as subsurface control accumulated, it became apparent that stratigraphic traps were dominant. In the 1970's, the primary interpretations of depositional environments for D Sandstone sediments were deltaic and fluvial with transitional and marine environments also represented.

By the late 1980's, a geological model was proposed which favored a valley-fill depositional system (Sonnenberg 1987). The D Sandstone interval, in this model, is divided 
into two sand-body types. The first or older unit was deposited during a regression at the end of Huntsman deposition. This unit is of regional extent and occurs across the entire western portion of the basin. The second or younger unit is a channel deposit (fluvial and estuarine) that accumulated as part of a valley fill. These valley-fill sediments were deposited in structurally low areas which are frequently associated with pre-D Sandstone faulting.

As the interpretation of D Sandstone reservoirs evolved from structurally to primarily stratigraphically controlled, interpreters of seismic data also began to realize that seismic amplitude of horizon-time events relating to the D Sandstone and adjacent formations should be indicators of reservoir development. As early as 1984, it was reported in the literature that channel complexes and valley fill deposits could be located at Zenith Field (Fig. I-2) using seismic techniques (Sonnenberg 1987). Seismic modeling of a 52-ft reservoir produced an amplitude peak and trough associated with the top and base of the D Sandstone, respectively, which diminished significantly as the sandstone thickness decreased. Amplitude responses were found in 2D seismic data across a D Sandstone valley-fill reservoir which were similar to the results from seismic modeling. Although stratigraphic interpretation of seismic data promised to be a boon for D Sandstone exploration, the method did not receive wide-spread acceptance. Possible reasons for this are 1) reluctance to look for D Sandstone reservoirs in areas which were structurally low during deposition and 2) inability to tie syntheticseismogram events with actual survey data because of phase rotation or lack of adequate sonic logs.

Waterflooding

Waterflooding of D Sandstone reservoirs began in the 1960's. Production by primary depletion from the D Sandstone has been good to excellent; however, secondary recovery by waterflooding has been disappointing. In 1974, there were 37 waterflood projects in the D Sandstone in Colorado according to a U.S. Bureau of Mines Report of Investigations (Biggs and Koch 1974). Data from the 37 D Sandstone waterfloods indicates incremental recovery of only $50 \mathrm{stb} / \mathrm{ac}-\mathrm{ft}$ by waterflooding from 65 percent of the projects. Waterflood projects in the general vicinity of the Sooner Unit had marginal to negative incremental reserves compared to primary production extrapolations. Table I-1 shows data from the waterflood projects in the area of the Sooner Unit.

Bureau of Mines Report of Investigations No. 7959, which tabulated statistics in 1974 on waterflooding oil fields in Colorado, is an excellent resource for production data from D Sandstone reservoirs in the Denver Basin. However, the authors of the report did not attempt to qualify the statistics on recovery by giving reasons for good or poor recovery. Coincidentally after the report was published, interest waned for waterflooding the D Sandstone in the Colorado portion of the Denver Basin. These statistics were subsequently used by engineers on technical committees for proposed waterflood projects to demonstrate that the D Sandstone was a poor waterflood candidate. Between 1974 and 1992, only two waterflood projects were approved by the Colorado Oil and Gas Commission. Some of the popular reasons which were proposed by engineers for poor waterflooding recovery were 1) high Dykstra-Parsons coefficient of permeability variation and 2) high gas-saturation at the end of primary depletion.

One of the D Sandstone fields found during the boom period for D Sandstone exploration is the Jackpot Field. The Jackpot Field is located in T. 6 N., R. 59 W. which is 
approximately 10 miles southwest from the Sooner Unit. Jackpot Field was discovered in 1955 from seismic mapping and subsurface control. Waterflood operations at Jackpot began in 1960. The D Sandstone sediments were described as discontinuous, lenticular transgressive sandstones (Webster 1982). The field was developed on 40-acre spacing with a maximum of 32 productive wells. The Jackpot Field project has the highest recovery by waterflood in the area around the Sooner Unit with a recovery factor of 31.9 percent of OOIP as shown in Table $\mathrm{I}-1$. However, the ratio of incremental oil recovered by waterflooding to recovery by primary is only 25 percent. The calculated OOIP for this field may be too low. The Jackpot Field waterflood project is a technical success, but probably an economic failure.

The average primary recovery of D Sandstone waterflood projects in the area surrounding the Sooner Unit, shown in Table 1, is 16.1 percent of OOIP. The total recovery after primary and waterflooding is 17.7 percent. An average incremental recovery of only 1.6 percent after waterflooding is demonstrated by these fields. All of these waterflood projects, except the Jackpot Field, are technical failures. The decision to risk waterflooding at the Sooner Unit was influenced to a large degree by the fact that the Sooner reservoir thickness is nearly double the average of the fields listed in Table I-1.

Table I-1

Recovery by Waterflood from D Sandstone Fields Near the Sooner Unit

\begin{tabular}{llllllll}
\hline \multirow{2}{*}{ Field Name } & $\begin{array}{c}\text { Township }- \\
\text { Range }\end{array}$ & $\begin{array}{c}\text { Area }- \\
\text { Acre }\end{array}$ & $\begin{array}{c}\text { Acre- } \\
\text { Feet }\end{array}$ & $\begin{array}{c}\text { OOIP- } \\
\text { Mbbl }\end{array}$ & $\begin{array}{c}\text { Primary } \\
\text { EUR-Mbbl }\end{array}$ & $\begin{array}{c}\text { Waterflood } \\
\text { EUR-Mbbl }\end{array}$ & $\begin{array}{c}\text { Recovery } \\
\text { Factor }\end{array}$ \\
\hline Bijou & $4-5 \mathrm{~N}, 59-60 \mathrm{~W}$ & 1180 & 11800 & 7410 & 1400 & 1570 & $21.2 \%$ \\
Bijou-West & $4 \mathrm{~N}, 60 \mathrm{~W}$ & 1320 & 14520 & 7540 & 1198 & 1211 & $16.1 \%$ \\
Buckingham & 8N, 58W & 480 & 5760 & 2740 & 389 & 389 & $14.2 \%$ \\
Greasewood & $6 \mathrm{~N}, 61 \mathrm{~W}$ & 240 & 1920 & 1235 & 248 & 267 & $21.6 \%$ \\
Jackpot & $6-7 \mathrm{~N}, 59 \mathrm{~W}$ & 1440 & 11520 & 5515 & 1381 & 1762 & $31.9 \%$ \\
Orchard-East & $4 \mathrm{n}, 60 \mathrm{~W}$ & 360 & 2160 & 1237 & 301 & 308 & $24.9 \%$ \\
Orchard-West & $4 \mathrm{~N}, 60 \mathrm{~W}$ & 200 & 1200 & 766 & 132 & 132 & $17.2 \%$ \\
Roggen-NW & $2 \mathrm{~N}, 63 \mathrm{~W}$ & 200 & 2000 & 1462 & 204 & 241 & $16.5 \%$ \\
Roggen-SE & $2 \mathrm{~N}, 63 \mathrm{~W}$ & 1050 & 10500 & 6267 & 496 & 552 & $8.8 \%$ \\
Masters & $5 \mathrm{~N}, 60 \mathrm{~W}$ & 360 & 2160 & 4070 & 335 & 354 & $8.7 \%$ \\
Total & & 6830 & 63540 & 38242 & 6084 & 6786 & $17.7 \%$ \\
\hline
\end{tabular}

Note: Waterflood EUR is total primary plus secondary recovery. 


\section{References}

Biggs, Paul and Charles Koch. 1974. Waterflooding of Oil Fields in Colorado, U.S. Bureau of Mines Report of Investigations No. 7959.

Haun, John D. 1963. "Stratigraphy of Dakota Group and Relationship to Petroleum Occurrence, Northern Denver Basin," in Guidebook to the Northern Denver Basin and Adjacent Uplifts, eds. P.J. Katch and D.W. Bolyard, (Denver: Rocky Mountain Association of Geologists): 119-134.

Hemborg, H. Thomas. 1993. "Denver Basin Plays -D Sand," in Atlas of Major Rocky Mountain Gas Reservoirs, ed. Carol L. Hjellming, (Socorro: New Mexico Bureau of Mines and Mineral Resources): 111-112.

Lavington, C.S. 1941. "Greasewood Oil Field," in Stratigraphic Type Oil Fields $-A$

Symposium, ed. A. I. Levorsen, American Association of Petroleum Geologists: 19-42.

Rountree, Russ. 1984. Rocky Mountain Oil History, (Denver, CO: Hart Publications, Inc.): $46-48$.

Sonnenberg, Stephen A. 1987. "Tectonic, Sedimentary, and Seismic Models for the D Sandstone, Zenith Field Area, Denver Basin, Colorado", The American Association of Petroleum Geologists Bulletin, 45(11): 1366-1377 (November 1987).

Volk, Richard W. 1972. "The Denver Basin and the Las Animas Arch", in Geologic Atlas of the Rocky Mountain Region, ed. W.W. Mallory, (Denver, CO: Rocky Mountain Association of Geologists).

Webster, Mark. 1982. "Jackpot Field", in Oil and Gas Fields of Colorado, Nebraska and Adjacent Areas, (Denver, CO: Rocky Mountain Association of Geologists). 


\title{
ADVANCED SECONDARY RECOVERY PROJECT FOR THE SOONER UNIT, WELD COUNTY, COLORADO \\ COOPERATIVE AGREEMENT DE-FC22-93BC14954
}

\author{
History of the Sooner "D" Sand Unit
}

Production from the D Sandstone was established in 1969 in the Sooner Field one mile east from the Sooner "D" Sand Unit (Sooner Unit) in section 27, T. 8 N., R. 58 W. Methods used for exploration and development in the area were geology from well logs and wildcatting. The field consisted of a single well until 1980, when four additional wells were completed. The first productive D Sandstone oil well within the confines of the current Sooner Unit boundary (NWSE section 28, T. 8 N., R 58 W.) was completed in December 1985. By 1988, the productive surface area of the Sooner Unit reservoir was defined at about 720 acres with wells spaced on regular 40 -acre production units. The 1440 -acre Sooner Unit was created in September 1989. At that time, the unitized area had produced 772,000 stocktank bbl (stb) of oil and 3,000,000 mcf of gas. The reservoir did not have a gas cap or freewater contact. Negligible formation water produced during primary depletion. Estimates of original-oil-in-place (OOIP) at the time the Sooner Unit was formed ranged from 5,300,000 to $5,900,000 \mathrm{stb}$. Estimates of ultimate primary recovery of oil by the unitization technical committee averaged $900,000 \mathrm{bbl}$ and ranged from 850,000 to $1,100,000 \mathrm{bbl}$.

The geological interpretation of the reservoir at the time of unitization was predominately a fluvial channel with associated splay deposits. The strategy for water injection was to inject in the center of the channel and at the northern and southern ends. Production was curtailed during fill-up for approximately one year.

At the time of unitization there were 17 active wells. Four wells were converted to water injection service. Figure II- 1 is a map of the reservoir area based on net-pay thickness and configuration of the original injection-production alignment. Water supply is from two wells completed in the J Sandstone which is approximately $100 \mathrm{ft}$ below the top of the D Sandstone. These two sandstones are separated by 40 to $80 \mathrm{ft}$ of Huntsman shale and Mowry siltstone.

When the Sooner Unit Class I project began in October 1992, there were 17 active D Sandstone wells, which consisted of 11 production wells, four water-injection wells and two gas-recycling wells. One well was shut-in and two wells were producing make-up water from the J Sandstone. Cumulative oil production was 1,086,133 bbl. The average oil rate from the total Unit was 332 bbl oil per day.

By December 1995, and at the end of the project, there were 15 active D Sandstone wells, which consisted of 11 production wells and four water-injection wells. Four D Sandstone wells were shut-in. One water-supply well was active and the other water-supply well was shut-in. Three new wells were drilled and completed in the D Sandstone. The two gas-recycling wells were converted to production service. Two producing wells were converted to water-injection service. One well was plugged during the project after an unsuccessful horizontal completion attempt. At the end of December 1995, cumulative oil production was 1,436,707 bbl and the average oil rate from the total Unit was $442 \mathrm{bbl}$ per day. Figure II-2 shows the monthly production from Sooner Unit wells since discovery. 


\title{
ADVANCED SECONDARY RECOVERY PROJECT FOR THE SOONER “D” SAND UNIT,
}

\author{
WELD COUNTY, COLORADO \\ COOPERATIVE AGREEMENT DE-FC22-93BC14954
}

\author{
Geology of the Sooner Unit and Adjacent Area
}

The Sooner "D" Sand Unit (Sooner Unit) is located approximately 100 miles from Denver in the central portion of the Denver Basin in T. 8 N., R 58 W., Weld County, Colorado (Fig. III-1). The Denver Basin is asymmetric and trends north-south, with the deepest part of the basin near Denver where sedimentary rocks exceed 13,000 ft. The basin was formed during the Laramide orogeny and the western portion of the basin has the greatest dip near the flank of the Rocky Mountain Front Range. The producing reservoir at Sooner Unit is the D Sandstone with an average net pay of $17 \mathrm{ft}$ at an average depth of $6,300 \mathrm{ft}$. The Sooner Unit reservoir is interpreted to be a valley fill estuary. The predominant sedimentary features in the Sooner Unit are fluvial point bars and shallow-water tidal bars. The reservoir is stratigraphically trapped on monocline with a dip angle of $0.4^{\circ}$ oriented at $288^{\circ}$ (Fig. III2).

The D Sandstone, a member of the Dakota Group, is of Upper Cretaceous age and occurs between marine shales (Fig. III-3). The base of the overlying Graneros Shale is the top of the D Sandstone. It is black, organic-rich marine shale. The top of the Graneros is marked by the ' $X$ ' bentonite bed, a wide-spread and correlative marker in the Denver Basin. The Huntsman Shale underlies the D Sandstone and is also a black, organic-rich, non-burrowed marine shale. The Graneros interval thickness is nearly constant from 94 to $106 \mathrm{ft}$ over a large area surrounding the Sooner Unit. Any significant thinning of this interval is interpreted to be the result of post-depositional normal faulting. The Huntsman ranges in thickness from 18 to $48 \mathrm{ft}$ (Fig. III-4). The variation of Huntsman thickness is related to erosion from the D Sandstone drainage system. A structure map of the top of the Huntsman shale shows the D Sandstone drainage system of the Sooner Unit reservoir (Fig. III-5).

At the end of Huntsman deposition, a regressive event (stage 1) began that deposited shoreline and shallow-marine sandstones across the basin (Fig. III-6). These sandstones are in transitional contact with the Huntsman. Slight fault block movement influenced sedimentation. Streams and deltas were positioned in topographically low areas and interdeltaic deposition occurred in topographically high areas. The regressive D Sandstone was deposited over the basin as the shoreline prograded seaward, approximately toward the northwest across the Sooner Unit area. Regional erosion and incisement occurred after the deposition of thin, regressive sandstones (stage 2). River and stream drainage incised through the older D Sandstone and into the underlying Huntsman Shale. The third stage of D Sandstone deposition occurred during a rise in sea level. During stage 3, the incised drainage were filled with fluvial and estuarine sandstones and siltstones.

There are several maps which can be made for reconstruction of paleo-structure. A map which corresponds well with production is the isopach from the ' $X$ ' bentonite to the Mowry (Figs. III-7). The ' $\mathrm{X}$ ' bentonite-Mowry interval ranges from 158 to $184 \mathrm{ft}$ and the thickest interval coincides with thickest D Sandstone and thinnest Huntsman Shale. The depositional model which most appropriately explains these thickness variations is that thicker D Sandstone-Huntsman Shale areas correspond to paleo-structurally low areas. These 
low areas are frequently bounded by normal faulting which occurred prior and concurrent with D Sandstone deposition (Sonnenberg 1982, Sonnenberg 1987 and Plybon 1983). This is demonstrated on log cross-sections (Fig. III-8) at the Sooner Unit and other fields. The faults in the Sooner Unit have a maximum displacement of $20 \mathrm{ft}$ and are nearly vertical. Seismic indications of thick D Sandstone sediments (amplitude and wavelet isochron) frequently correspond to basement faults. Huntsman shale thickness of less than $38 \mathrm{ft}$ at the Sooner Unit and adjacent area represents erosional down-cutting by the D Sandstone drainage system. Productive valley-fill sediments are found in and immediately adjacent to these thin areas. Productive D Sandstone reservoirs associated with thick Huntsman exhibit a coarseningupward character on electrical logs. These reservoirs are more marine in character and probably resulted from winnowing on subtle high areas.

The shape of the Sooner Unit reservoir is that of a funnel-mouth estuary. The mouth of estuary or valley-fill is located at to the north while the up-stream neck is located at the south end of the reservoir. To the north of the Sooner Unit is the Lilli Field (Fig. III-2). The Lilli Field is an east-west trending double-lobed marine bar. The Lilli Field produces from a stage-3 D Sandstone which was winnowed on a slight paleo-structural high. Immediately to the east of the Sooner Unit is another D Sandstone reservoir which is a bifurcation of the erosional valley system found in the Sooner Unit (Fig. III-4).

The predominant sedimentary features in the Sooner Unit are fluvial point bars and shallow-water tidal bars (stage -2 and stage -3 deposition). There are fine to medium-grained fluvial deposits with gross thickness of up to $55 \mathrm{ft}$. These are identified from a bell-shaped $\log$ character with the most permeable and porous rock at the base and a fining-upward character. Identification of valleys does not guarantee thick reservoir-quality rock. Some areas of thick sediments are filled with muddy siltstone with low porosity and permeability (Fig. III-9). Regional and non-productive stage-1 D Sandstone is found in all the dry holes surrounding the Sooner Unit (Fig. III-8).

A similar D Sandstone reservoir to the Sooner Unit can be found at Zenith Field in Adams County, Colorado (Fig. III-1). This field also produces from channel deposits in a valley-fill system (Sonnenberg 1987). The field is located on a regional monocline without structural closure as is the Sooner Unit reservoir. The Zenith reservoir is stratigraphically trapped as a result of facies changes of porous, permeable stage -2 and stage -3 deposits to more silty stage -1 deposits. The regional regressive stage -1 sandstones that are adjacent to the valley fill are non-productive. The field had a solution-gas drive and produced no water. The same criteria used at Zenith Field to identify productive intervals apply quite well at the Sooner unit. These include: 1) resistivity of greater than $30 \mathrm{ohm}-\mathrm{m}, 2$ ) gamma ray of less than 30 API units, micro-resistivity and caliper log readings indicating mud-cake buildup and 3) density $\log$ porosities of greater than 8 percent. The similarities between the Sooner Unit and Zenith Field indicate that the valley-fill model is applicable across much of the Denver Basin.

Most of the petroleum produced from D Sandstone reservoirs has been from stratigraphic traps. In the Sooner Unit and adjacent area, the fields do not have structuralclosure and do not produce formation water. The more prolific recoveries per well and per acre have been found in the thicker valley-fill reservoirs. Identification of areas with the most potential for prolific production depends on recognition of valley systems and paleostructurally low areas by mapping the thickness of the Huntsman Shale and ' $\mathrm{X}$ ' bentoniteMowry interval. While many D Sandstone exploration targets have been based on structural 
closure or nosing, these elements are often found to actually have negligible impact on reservoir quality or trapping after development drilling is finished.

\section{References}

Plybon, Steven C. 1983. "Seismic-Stratigraphic Investigation of the D Sandstone at Masters Field, Weld County, Colorado," Masters Thesis No. 2781, Colorado School of Mines, Golden, Colorado.

Sonnenberg, Stephen A. 1982. "The Lanyard Field, a Structural-Stratigraphic Trap, Denver Basin, Colorado," The Mountain Geologist, 19(3): 63-72 (July 1982).

Sonnenberg, Stephen A. 1987. "Tectonic, Sedimentary, and Seismic Models for the D Sandstone, Z Zenith Field Area, Denver Basin, Colorado," The American Association of Petroleum Geologists Bulletin, 45(11): 1366-1377 (November 1987). 


\title{
ADVANCED SECONDARY RECOVERY PROJECT FOR THE SOONER “D” SAND UNIT,
}

\author{
WELD COUNTY, COLORADO \\ COOPERATIVE AGREEMENT DE-FC22-93BC14954
}

Petrographical Analysis of the D Sandstone

Introduction

Whole and sidewall cores were described from five wells. Two of these wells are in the Sooner Unit and four are in nearby fields. Thin-sections were taken and analyzed from the two wells in the Sooner Unit. The petrographical analysis helped define the estuarine depositional setting for the D Sandstone reservoir and support a basin-wide depositional model for the D Sandstone as a valley fill system. Petrographical analysis shows two types of deposition in the Sooner Unit reservoir. Lower and older fluvial sandstones are characterized by kaolinite clays. Upper and younger sandstones are more estuarine in nature and are characterized by calcite and opal cements with burrowing by marine organisms. Root structures and carbonaceous shales also confirm the estuarine setting at the Sooner Unit D Sandstone reservoir. The primary component of D Sandstone at the Sooner Unit is monocrystalline quartz which is fine-grained with a size of $0.163 \mathrm{~mm}+/-0.045 \mathrm{~mm}$. Tables IV-1 and IV-2 summarize composition and grain size from D Sandstone thin-section study. Major cements include iron oxide, clay and quartz. There are insufficient core data to determine if these cements constitute any significant component of reservoir compartmentalization. The main benefit derived from the petrographical analysis was from formulation of the depositional setting with well $\log$ data.

Description of D Sandstone from SU 7-21

The reservoir rock from the SU 7-21 core contains very fine-grained sandstone, quartz to sub-arkosic arenite, styolites in thin clay laminae, ripple-drift cross-strata, trough classbeds, clay clasts, lenticular and flaser bedding (Fig. IV-1). The overlying cap rock is described as alternating shale and siltstone, with alternating laminate of high bioturbation and low to no bioturbation, horizontal and vertical burrows, some escape burrows, some laminae of shale with coal or organic with pyrite concretions. The underlying Huntsman Shale is described as uniform, dark-grey shale with no obvious bioturbation. The density log from the SU 7-21 well is shown in Figure IV-2.

Description of D Sandstone from SU 14-21-1

Nine sidewall-eore samples were obtained and examined from the D Sandstone interval in SU 21-14-1. The samples were obtained with Schlumberger's sidewall drilling tool. A cut of each sample was impregnated with blue epoxy to allow estimation of porosity and thin sections were made. Detailed petrographic descriptions are found in Table IV -3 and the density-porosity log from the SU 21-14-1 is shown in Figure IV-3. These petrographical examinations were integrated with previous petrographical work from the SU 7-21 core (SWNE Sec 21). 
Core samples show the D Sandstone interval to be fine-grained to very-fine-grained quartz arenite (to sub-arkose) sandstone which is inter-bedded with calcareous, organic-rich silt and clay. The sandstone is generally well sorted with sub-angular to rounded grains. Mono-crystalline quartz is the dominant grain type. Other grains include feldspar (often altered to sericite), chert, calcareous siltstone clasts, and muscovite mica. Quartz overgrowths are the most volumetrically significant type of cement. They were preceded only by clay-rim cement. Other cements include calcite, brown clay (pelloidal texture, possibly iron oxide stained), opal, chlorite and illite clay, and kaolinite clay with vermiculite texture. The D Sandstone has been divided into three benches from youngest to oldest; upper (D1), middle (D2) and lower (D3),. Summary descriptions of each bench follow.

D1 and D2, Upper and Middle Benches (6269 -6296ft)

The upper and middle benches of the D Sandstone in the SU 21-14-1 well are generally finer grained, more finely inter-laminated with clay and silt-rich material, and have much less porosity than those found in the SU 7-21 well. Primary inter-granular porosity is almost always occluded by a variety of cements. The most volumetrically important of these include calcite, clay rims, and quartz over-growths. Non-kaolinitic clay pore-fill and minor amounts of opal pore-fill are also present. Secondary (leached) porosity is present in two samples at $6251 \mathrm{ft}$ and $6258 \mathrm{ft}$ (Fig. IV-3).

The abundance of calcite cement and chloritic, illitic (?) clay-types suggests a more marine-water composition of pore fluids. Finer grain size and abundant clays suggest deposition in a quiet water environment, possibly in a protected estuarine setting.

\section{D3 Lower Bench (6238 -6268ft)}

Porosity is best developed in the sample at $6279 \mathrm{ft}$ (Fig. IV-3). This sample shows a combination of preserved primary inter-granular porosity (not occluded by quartz overgrowths) and secondary porosity. The secondary porosity appears as oversized pores developed when feldspar grains or calcite cement were dissolved (leached). Permeability should be good in this interval since inter-granular pore systems generally have a high degree of connectivity. This zone and the one immediately below at $6290 \mathrm{ft}$ are the best sorted, coarsest grained and with least clay-rim cement. Porosity is less at $6290 \mathrm{ft}$ due to extensive development of quartz over-growths. Porosity occlusion in the zone at 6258 and $6272 \mathrm{ft}$ is controlled by kaolinite clay pore-fill with a distinctive vermiculite texture. This interval is fine grained with clay rim cements, finely inter-laminated silty clay layers, and calcareous siltstone clasts.

Reservoir quality is best developed in sandstones which were deposited in higher energy environments, incompletely cemented by quartz over-growths, and exposed to waters that leach feldspar grains. Kaolinite is a clay typically associated with soil development in sub-aerially exposed environments. These characteristics are typical of fluvial deposits in an exposed alluvial-plain setting

Stratigraphic Analysis

Correlation between the Sooner Unit 21-14-1 and the Sooner Unit 7-21 (Fig. IV-4) 
indicates that the D Sandstone is thicker and more clay-rich in the Sooner Unit 21-14-1. The D Sandstone is bracketed between the high gamma-ray shales in the J Silt (below) and the Graneros Shale (above) which represent periods of quiet-water deposition during maximum marine transgression. These are maximum-flooding surfaces (MFS) in sequence stratigraphy. Correlation from these flooding surfaces reveals that the D3 bench is an additional sand package in the SU 21-14-1 which includes the reservoir inter-valley and the kaolin clay-rich sands. This interval is bounded at the base by an erosional-sequence boundary (SB) which was the floor of an incised valley system. It is bounded at the top by a transgressive surface (TS) and represents the low-stand systems tract in this area. The upper-sandstone package (D1 and D2 benches) is of similar thickness in the SU 21-14-1 and 7-21 wells. These sands are characterized by calcite cements and burrowing by marine organisms. They were deposited during marine transgression into the valley system. Root structures and carbonaceous shales found in the SU 7-21 core suggest that these sands were deposited in an estuarine environment. They are bounded at the top eroding surface and generally fine upward. This interval is the transgressive-systems tract in sequence stratigraphy. The D1 and D2 benches are coarser grained and less clay-rich in the SU 7-21 than in the SU 21-14-1. They are oil reservoirs at the SU 7-21 and non-productive at the SU 21-14-1. The trend of quality sands is elongate parallel to the estuary margin. These sands were probably deposited as estuarine bar sands similar to those described by Allen and Posamentier at the Gironde Estuary, France.

\section{Reservoir Compartmentalization}

The low-stand and transgressive-systems tracts are characterized by different reservoir compartmentalization styles. Low-stand sands were deposited in fluvial point bars which were separated by clay-rich channel-fill along depositional strike (north-south to northwestsoutheast). They are restricted to the deepest part of the incised valley and probably separated into reservoir pods along that trend. The most effective vertical-flow barrier is probably the kaolinitic clay pore-fill between the low-stand (D3) and transgressive (D1 and D2) sandstones.

Transgressive sands were deposited in a setting with increasing accommodation space during marine transgression. Consequently, they cover a wider area and are more aggradational in nature. Within the estuarine environment, elongate bar sands develop parallel to depositional strike. These bar sands form the reservoir compartments in the D1 and $\mathrm{D} 2$ benches.

Summary and Conclusions

Petrographic study of core data can tell much about reservoir heterogeneity by establishing elements indicative of depositional setting. The petrographic studies of the Sooner Unit D Sandstone established an estuarine setting. This allowed review of literature which described estuaries. Descriptions of modern estuaries helped visualize the Sooner Unit reservoir in the subsurface and orientation of sedimentary features. 
Table IV-1

Composition of D Sandstone from Thin-Section Analysis

\begin{tabular}{ll}
\hline Component & Percentage \\
\hline Mono-crystalline Quartz & $66.5 \%$ \\
Poly-crystalline Quartz & $7.2 \%$ \\
Potassium Feldspar & $0.8 \%$ \\
Plagioclase & $0.5 \%$ \\
Mica & $0.8 \%$ \\
Rock Fragments & $2.5 \%$ \\
Clay Cement & $6.4 \%$ \\
Iron Oxide Cement & $7.2 \%$ \\
Calcite Cement & $1.0 \%$ \\
Opal Cement & $2.9 \%$ \\
Quartz Cement & $4.0 \%$ \\
Total & $100.0 \%$ \\
\hline
\end{tabular}

Table V-2

Grain Size for D Sandstone from Thin-Section Samples

\begin{tabular}{llll}
\hline Sample & $\begin{array}{c}\text { Mean } \\
\text { Size }(\mathrm{mm})\end{array}$ & $\begin{array}{c}\text { Standard } \\
\text { Deviation }\end{array}$ & Verbal \\
\hline 1 & 0.179 & 0.043 & Fine \\
2 & 0.157 & 0.047 & Fine \\
3 & 0.160 & 0.047 & Fine \\
4 & 0.158 & 0.044 & Fine \\
5 & 0.325 & 0.108 & Medium \\
6 & 0.116 & 0.044 & Very Fine \\
\hline
\end{tabular}

Mean size was determined by measurement of apparent long axesof 40 randomly selected mono-erystalline quartz grains per thin section. 
Table IV -3

D Sandstone Petrographic Descriptions from SU 21-14-1

Depth Description of thin-section from sidewall core

$6243 \mathrm{ft} \quad$ Calcareous siltstone inter-laminated with very-fine-grain quartz sandstone, no visible porosity, micaceous, abundant pyrite.

$6247 \mathrm{ft}$

Very-fine-grain quartz sandstone inter-laminated with calcareous, clayrich siltstone and organic-rich micro-styolites. Sandstone shows no visible porosity, primary inter-granular porosity has been occluded by cements; including clay rims, calcite pore-fill, opal and quartz overgrowths; rare, brown pelloidal clay clasts.

$6251 \mathrm{ft}$

Very-fine-grain quartz sandstone inter-laminated with calcareous, clayrich siltstone and organic-rich micro-styolites. Sandstone shows up to $10 \%$ porosity as over-sized pores (secondary porosity due to dissolution of feldspar grains and/or calcite cement). Primary inter-granular porosity has been occluded by clay rims, quartz overgrowths and minor opal and dark-brown clay (possibly iron oxide) pore-fill.

$6258 \mathrm{ft} \quad$ Very-fine-grain quartz sandstone inter-laminated with calcareous, clayrich siltstone and organic-rich micro-styolites. Ripple cross-lamination in sandstone layer. Sandstone shows up to $5 \%$ porosity as over-sized pores (secondary porosity due to dissolution of feldspar grains and/or calcite cement). Primary inter-granular porosity has been occluded by clay rims, quartz overgrowths and minor opal and dark-brown clay (possibly iron oxide) pore-fill.

$6272 \mathrm{ft}$

Very fine grain quartz sandstone (40\%), well-sorted, with no visible porosity. Primary inter-granular porosity has been occluded by kaolinite clay with vermiculite texture. Sandstone includes less than $10 \%$ feldspar (altered to sericite), chert, calcareous siltstone and muscovite grains. Sandstone is inter-laminated with calcareous, micaceous, clay-rich siltstone $(60 \%)$ and organic-rich micro-styolites.

$6276 \mathrm{ft}$

Fine-grain quartz sandstone with up to $10 \%$ feldspar, moderately wellsorted, $5 \%$ porosity (both primary inter-granular and secondary grain dissolution). Cements include quartz overgrowths, clay rims, and kaolinite clay pore-fill with vermiculite texture. Sample contains thinly laminated calcareous, micaceous, clay-rich siltstone and organic-rich micro-styolites in upper $20 \%$. 
Table IV -3

D Sandstone Petrographic Descriptions from SU 21-14-1

$6279 \mathrm{ft} \quad$ Fine-grain quartz sandstone, well-sorted, with up to $10 \%$ feldspar (Plagioclase altering to sericite), muscovite mica, and distorted siltyclay clasts. Cement includes quartz overgrowths and possibly feldspar overgrowths. Observed $15 \%$ porosity, about half preserved primary inter-granular and half secondary dissolution of feldspar grains. Minor authigenic calcite rhombs, kaolinite clay, and chlorite clay associated with mafic grains.

$6290 \mathrm{ft} \quad$ Fine grain quartz sandstone, well-sorted, with mineral assemblage as at $6279 \mathrm{ft}$. Primary inter-granular porosity is almost completely occluded by quartz $(+/$-feldspar) overgrowth cement. Observed $3 \%$ porosity is entirely secondary dissolution of feldspar, mica, and/or calcite.

$6295 \mathrm{ft} \quad$ Very fine quartz sandstone inter-laminated with calcareous, micaceous, clay-rich siltstone and organic-rich micro-styolites. Cements include quartz overgrowths and kaolinite clay pore-fill with vermiculite texture. Observed less than $1 \%$ micro-porosity associated with incomplete clay pore-fill and possible calcite dissolution.

\section{References}

Allen, G.P. and H. W. Posamentier. 1993. "Sequence Stratigraphy and Facies Model of an Incised Valley Fill: The Gironde Estuary, France," Journal of Sedimentary Petrology, 63(3): 378-391 (May 1993). 


\title{
ADVANCED SECONDARY RECOVERY PROJECT FOR THE SOONER “D” SAND UNIT,
}

\author{
WELD COUNTY, COLORADO \\ COOPERATIVE AGREEMENT DE-FC22-93BC14954
}

Core and Electrical Log Descriptions of the D Sandstone

Basic to the characterizations of the D Sandstone reservoir at the Sooner Unit are data from conventional core analysis and electrical log calculation. The permeability-porosity cross-plot from D Sandstone cores is shown in Figure V-1. The plot suggests a porosity cutoff of between 6 and 8 percent for determination of net pay. The average net-pay porosity of the Sooner Unit reservoir is 11.5 percent. Statistics for permeability are summarized in Table $\mathrm{V}-1$. The tabulation is intended to show that a permeability cut-off of $0.5 \mathrm{md}$ is probably appropriate and a value of 0.74 for Dykstra-Parsons coefficient of permeability variation results when a log-normal frequency plot is made as shown in Figure V-2.

Calculations of net-pay properties from electrical logs are summarized in Table $\mathrm{V}-2$. Net-pay thickness averages $17 \mathrm{ft}(+/-8 \mathrm{ft})$ with a maximum of $34 \mathrm{ft}$. At the Sooner Unit, criteria used to identify productive intervals include 1) resistivity of greater than $30 \mathrm{ohm}-\mathrm{m}, 2$ ) gamma ray of less than 30 API units, micro-resistivity and caliper log readings indicating mud-cake buildup and 3) density $-10 g$ porosities of greater than 8 percent. Calculations of water saturations are qualitative but are performed with reasonable success using a standard Archie equation for sandstones. The formation water is very fresh and a value of $0.06 \mathrm{ohm}-\mathrm{m}$ is used for water resistivity $\left(\mathrm{R}_{\mathrm{w}}\right)$ at formation temperature of $220^{\circ} \mathrm{F}$. Using the mediuminduction curve value for formation resistivity $\left(R_{t}\right)$ produces reasonable values for water saturation. A shale content of 35 percent from gamma-ray readings and water saturation of 60 percent are used to discriminate the net-pay from non-reservoir rock as summarized in Table V-2. The D Sandstone did not produce formation water during primary depletion and it is assumed that the reservoir water saturation was initially at irreducible conditions. Special core analysis indicates a value for irreducible water saturation of 19 percent.

Table V-1

Permeability Data from Four D Sandstone Cores in the Sooner Unit Area

\begin{tabular}{lcrr}
\hline & 0.1 md cutoff & 0.5 md cutoff & 1.0 md cutoff \\
\hline Geometric Mean k & 8.8 & 21.3 & 23.6 \\
Median Value k & 20.8 & 28.0 & 28.2 \\
Dykstra-Parsons & 0.890 & 0.744 & 0.715 \\
Coef. of Variation & & & \\
Cumulative Capacity & $99.9 \%$ & $99.8 \%$ & $99.7 \%$ \\
\hline
\end{tabular}


Table V-2

Summary of Log Calculations from 23 wells in the D Sandstone at the Sooner Unit

\begin{tabular}{lrcccc}
\hline & $\begin{array}{c}\text { Net Pay } \\
\text { Thickness } \\
\text { (feet) }\end{array}$ & $\begin{array}{c}\text { Porosity } \\
\text { Thickness } \\
\text { (feet) }\end{array}$ & $\begin{array}{c}\text { Hydro- } \\
\text { carbon } \\
\text { Thickness } \\
\text { (feet) }\end{array}$ & $\begin{array}{c}\text { Average } \\
\text { Porosity }\end{array}$ & $\begin{array}{c}\text { Oil } \\
\text { Saturation }\end{array}$ \\
\hline Maximum & 34.0 & 2.887 & 3.725 & $11.0 \%$ & $77.5 \%$ \\
Mean & 16.6 & 1.408 & 1.899 & $11.5 \%$ & $74.1 \%$ \\
Median & 19.0 & 1.363 & 2.052 & $10.8 \%$ & $66.4 \%$ \\
Standard Deviation & 8.2 & 0.892 & 1.110 & $1.4 \%$ & $5.5 \%$ \\
\hline
\end{tabular}




\title{
ADVANCED SECONDARY RECOVERY PROJECT FOR THE SOONER “D” SAND UNIT,
}

\author{
WELD COUNTY, COLORADO \\ COOPERATIVE AGREEMENT DE-FC22-93BC14954
}

Pressure Transient Analysis of the D Sandstone

Pressure transient testing was performed at injection and production wells. The duration of these pressure tests were from 72 to 120 hours. Permeability to water at injection wells ranged from 5 to $50 \mathrm{md}$ and most wells indicate negative skins from -2 to -4 . All wells in the Sooner Unit have been hydraulically fractured. The character from plots of the pressure transient data indicate late-time linear or bi-linear flow which is most likely resulting from reservoir heterogeneity. Evaluations of the pressure transient data using analytical simulation and type curves indicate channel-widths which average $610 \mathrm{ft}$. The analyses from injectionwell data are summarized in Table VI-1.

Table VI-1

Summary of Pressure Fall-off Analysis from Water Injection Wells

\begin{tabular}{lrrr}
\hline & $\begin{array}{c}\text { Transmissibility } \\
\text { Wh/ } \mu \text { B } \\
(\mathrm{md}-\mathrm{ft} / \mathrm{cp})\end{array}$ & Skin & \multicolumn{2}{c}{$\begin{array}{c}\text { Bi-linear Flow } \\
\text { Width } \\
(\text { feet })\end{array}$} \\
\hline SU 2-21 & 3641 & -4.3 & 905 \\
SU 3-21 & 650 & -3.3 & 684 \\
SU 10-21A & 1106 & -4.6 & 490 \\
SU 10-28 & 400 & -2.0 & 363 \\
Average & 1449 & -3.6 & 610 \\
\hline
\end{tabular}

Most of the pressure tests could not be matched by type-curves or simulation without inclusion of nearby barriers in the analysis. These dimensions appear to be valid when compared to the dimensions and shapes on map displays of various 3D seismic attributes of the D Sandstone and related horizons. 


\title{
ADVANCED SECONDARY RECOVERY PROJECT FOR THE SOONER “D” SAND UNIT,
}

\author{
WELD COUNTY, COLORADO \\ COOPERATIVE AGREEMENT DE-FC22-93BC14954
}

Seismic Characterizations of the D Sandstone

Introduction

Fluvial and valley-fill hydrocarbon reservoir systems are frustrating to the explorationist and development engineer-geologist. This is because they exhibit a high degree of lateral and vertical heterogeneity. Countless examples can be given where nearoffset and replacement wells encountered unpredicted and dramatic changes in reservoir development. During waterflood operations, effects from heterogeneity and anisotropy of the reservoir are magnified over what is observed during primary depletion. It is concluded that regular well spacing of 40-acre patterns is not efficient for waterflooding fluvial and valleyfill D Sandstone reservoirs in the Denver Basin. While infill drilling at 20-acre spacing and developing D Sandstone fields on regular five-spot injection patterns would recover most of the moveable oil, it is not economically efficient. Integrated reservoir characterization with 3D seismic can optimize infill locations with the minimum number of wells to maximize economic benefit. A method is presented which has successfully integrated 3D seismic attributes with electric-log and well-performance data for the purpose of drilling low-risk and high-recovery wells. While interpreters of 2D and 3D seismic in the Denver Basin have been able to resolve the general limits and outline of valley fill systems in the D Sandstone with single attributes such as amplitude, it is possible to improve resolution of compartmentalization by using multiple attributes of the D Sandstone and adjacent temporal horizons.

The acquisition of 3D seismic does not result in an easy and immediate interpretation of D Sandstone reservoirs. This is because reservoir development is primarily stratigraphic in nature and it is relatively thin at a maximum gross thickness of $70 \mathrm{ft}$ with an average of $30 \mathrm{ft}$. It is possible with patience and systematic analysis to not only produce maps representing stratigraphic variability but to also quantify (with an error range) reservoir development in terms of net feet and porosity-feet.

Seismic Acquisition and Processing

The Sooner Unit 3D seismic data were recorded October 8-17, 1992. The source was created with four LRS $-315 \mathrm{FC}$ vibrators. Twenty receiver lines were surveyed east-west and spaced $800 \mathrm{ft}$ apart. Twenty-five source lines were oriented north-south and were spaced 600 $\mathrm{ft}$ apart. The $200 \mathrm{ft}$ source-spacing used on each source line allowed four vibration points (VP) to be recorded between each pair of receiver lines. A total of $732 \mathrm{VPs}$ were recorded to create the 3D data volume. The source and receiver coverage extended beyond the boundaries of the Sooner Unit so a stacking fold of 20 or more would begin immediately inside the Sooner Unit boundary. The initial processing steps of the Sooner 3D data are shown in table VII-1. 
Interpretation

Three synthetic seismograms (from sonic and density log data in the 3D survey area) and a vertical seismic profile (VSP) taken in SU 10-21A at time of 3D data acquisition were used to calibrate initial interpretation efforts. The calibration identified the D Sandstone at approximately $1.456 \mathrm{sec}$ two-way time (TWT). The analysis also indicated the zero-phase synthetic seismograms best tie reverse-polarity seismic data. Picking of events was done on reverse-polarity (zero-phase) data. The correlation of the VSP to surface seismic data is good at the D Sandstone but deteriorates uphole. It is fortunate that one of the electrical-log suites used for construction of synthetic seismograms was from a well which was drilled to the Permian Ingelside (8133 ft total depth) as the Plainview (6646 ft) is a strong reflector below the D and J Sandstones (6308 ft and $6388 \mathrm{ft}$, respectively). A seismic section, shown in Figure VII-1, from the Sooner 3D data volume shows the relationship of these reflectors. It is concluded that synthetic seismograms from good-quality sonic and density logs are sufficient to calibrate seismic data with formation horizons in the Sooner Unit area. A suite of logs through the Plainview formation is recommended for a high-confidence calibration.

The amplitude and isochron of the D Sandstone temporal event are good indicators of the general valley-fill system geometry and limits, but there are inconsistencies between these seismic attributes and good reservoir development. After additional study of synthetic seismograms and creating many maps of direct and complex seismic attributes of the D Sandstone and adjacent temporal horizons, it became clear that there was not a single attribute that best describes the Sooner Unit reservoir.

Synthetic Seismic Stratigraphic Modeling

As early as 1984, it was reported in the literature that channel complexes and valleyfill deposits could be located at Zenith Field in Adams Co., Colorado using seismic techniques (Sonnenberg 1987). Seismic modeling of the 52-ft reservoir at Zenith field produced an amplitude peak and trough associated with the top and base of the D Sandstone, respectively, which diminished significantly as the sandstone thickness decreased. Amplitude responses were found in 2D seismic data across the Zenith D Sandstone valley-fill reservoir which were similar to the results from seismic modeling. The initial seismic modeling for the Sooner 3D survey indicated that amplitude of the D Sandstone event would be a primary attribute for interpretation. Figure VII-2 is a synthetic seismogram section which shows amplitude variation with sandstone thickness from log data from the Sooner Unit. Amplitude decreases in the D Sandstone interval are primarily the result of thinning of valley-fill sediments or diminished acoustic contrast caused by lithological changes in the valley-fill sediments. Map view of the D Sandstone amplitude attribute displayed obvious inconsistencies with reservoir development of pay thickness and porosity feet. This resulted in a lack of confidence for this attribute and other seismic attributes to produce maps suitable for targeted infill drilling. Further synthetic seismic modeling was performed with log data from the Sooner Unit reservoir to determine resulting seismic signature and seismic frequency 
content necessary to resolve the internal stratigraphic architecture within the D Sandstone interval and to confirm mapping and interpretation methodologies from earlier work during the project. Stratigraphic cross-sections of the D Sandstone interval were constructed across the central portion of the unit, running west to east. Stratigraphic correlation of well log data suggests that the D Sandstone interval can be subdivided into a series of vertically stacked reservoir flow units that may be related to sequence stratigraphic events or surfaces (Fig. VII3). This reservoir unit correlation scheme was subsequently employed as geometric control for seismic modeling to determine the impact of the internal stratigraphic architecture on seismic response and potential vertical and lateral resolution limitations.

A seismic cross-section model was built across the Sooner Unit erosional valley. Synthetic seismograms were generated for each well using sonic-log data or transformed resistivity-log data. All correlations between well locations and stratigraphic boundary conditions for the seismic cross-section modeling were based on the stratigraphic correlations. As a result, the synthetic seismic model geometry represents the D Sandstone internal stratigraphic architecture as interpreted from log correlation and production behavior.

A series of Ricker wavelet filters, at different frequencies, were applied to the synthetic cross-section model to determine the frequency content necessary to resolve internal stratigraphy. Ricker wavelets were used on all models and at all frequencies for simplicity and to remove any possibility of wavelet side-lobe interference of the modeled seismic response. Wavelet extraction from the Sooner 3D seismic data, over the Niobrara to Dakota interval, reveals broad frequency spectra with central frequencies in the 45 to $50 \mathrm{~Hz}$ range and with usable, high-end frequencies in the range of 70 to $85 \mathrm{~Hz}$.

Generation of a $50 \mathrm{~Hz}$ model shows that internal D Sandstone stratigraphy is not resolvable into separate seismic events at this frequency. A general broadening of the seismic peak associated with the D Sandstone is observed where the gross sand thickness is greatest $(65 \mathrm{ft})$ in the stratigraphic cross-section. A model generated at $75 \mathrm{~Hz}$ does not differ greatly from the $50-\mathrm{Hz}$ model. No appreciable increase in resolution is gained at these slightly higher frequencies. Modeling at 50 and $75 \mathrm{~Hz}$ shows similar results as exhibited by the initial seismic modeling effort. As gross sand thickness increases, a corresponding increase is observed of the D Sandstone peak-amplitude and Huntsman shale trough-amplitude. Isochron thickening is also observed between the D Sandstone and Huntsman events. As 50 to $75 \mathrm{~Hz}$ seismic data were recorded during the 3D acquisition at the Sooner Unit, observations from the synthetic seismic modeling offer the most reasonable and costeffective methodologies for D Sandstone development and exploitation.

Seismic modeling at higher frequencies was also done to establish seismic parameters necessary to resolve internal stratigraphy. A $100-\mathrm{Hz}$ model begins to show resolution of D Sand stratigraphy with initial development of a lower, secondary seismic peak within the D Sand interval in thicker D Sandstone fill. At $125 \mathrm{~Hz}$, the seismic modeling shows full development of a secondary peak and trough pair which are coincident with increased erosion of the Huntsman and thicker D Sandstone fill in the valley system. This model also exhibits sharp lateral boundaries truncating the lower D Sandstone seismic peak. This sharp valley (channel) boundary is also observed in the dramatic isochron thinning of the Huntsman to J Sandstone (trough-peak) interval.

A final model was created at $300 \mathrm{~Hz}$ which fully resolves internal D Sandstone stratigraphy. Tops and bottoms of individual sandstones of 8-12 ft are observable as separate seismic events. Abrupt channel boundaries are observable as sharp character and phase 
changes in the synthetic model. At $300 \mathrm{~Hz}$, a significant amount of background noise is evident in the modeling, both within and outside of the valley trend.

Synthetic seismic modeling, constrained by stratigraphic correlation, shows that D Sandstone internal stratigraphic architecture is resolvable into individual seismic events with data frequencies of $125 \mathrm{~Hz}$ or greater. While surface seismic data with frequencies in the range of $125 \mathrm{~Hz}$ to $150 \mathrm{~Hz}$ have been acquired in several producing fields, the increased cost related to this acquisition would be substantial due to the increased source effort and downspacing of receiver and source points. Models with frequency content between $250 \mathrm{~Hz}$ and $300 \mathrm{~Hz}$ exhibit the greatest resolution of D Sandstone internal stratigraphy, with added background noise resulting from slight lithological and impedance variations. At present, it is not technically feasible to acquire $300 \mathrm{~Hz}$ surface seismic data at these depths. These very high frequencies can only be acquired with cross-wellbore seismic tomography techniques. At less than $125 \mathrm{~Hz}$ frequencies, vertical stratigraphy is not resolvable and gross thickness variations can be estimated from analysis of seismic amplitude and isochron data. Higher frequencies would result in higher confidence for detection of stratigraphic variation, but at significantly higher seismic costs. Interpretation methodologies would vary slightly according to the frequency content of the data.

\section{Seismic Attribute Correlation}

The D Sandstone is a seismic thin bed at the frequencies recorded at the Sooner D Sandstone Unit (Sooner Unit) and produces a single wavelet at the D Sandstone temporal horizon at the frequencies recorded. Initial seismic modeling during this project indicated that the amplitude of the D Sandstone event would be the primary indicator of reservoir-quality sandstone development. Figure VII-2 shows modeled amplitude increasing with D Sandstone thickness. After mapping the D Sandstone amplitude at the Sooner Unit, it became clear that there were many places of poor correlation between good reservoir development and amplitude response, although the amplitude defines the approximate limits of the valley fill or estuarine system. Figure VII-4 shows the amplitude from the D Sandstone horizon in map view. Notice the amplitude in the northeast portion of the Sooner Unit indicates a strong amplitude response over several dry holes which are thin and have no reservoir-quality rock. The amplitude map indicates several interesting features and patterns, but the use of this attribute alone for reservoir interpretation is not recommended. The isochron of the D Sandstone seismic event is shown in Figure VII-5. The D Sandstone isochron is not exactly coincident with amplitude.

Ten seismic attributes were picked from the D Sandstone and adjacent horizons in an effort to find attributes with better correlation by empirical methods. These included simple attributes (such as amplitude and isochron) and more complex attributes (such as phase and frequency). The seismic data, measured at bin locations each $100 \mathrm{ft}$ in the reservoir, provide higher spatial resolution than $1320-\mathrm{ft}$ (40-acre) well spacing. Reservoir properties measured at the well locations were integrated with the 3D seismic data to provide correlation between data gathered at different spatial intervals. Petrophysical properties from 36 wells were calculated from digitized electrical logs. The petrophysical properties included gross thickness, net-pay thickness, porosity feet and hydrocarbon feet. Multiple linear regressions were then performed to correlate the seismic attributes with petrophysical values and it was found that correlation coefficients of multiple attributes are higher than for any single 
attribute. Maps were then constructed from these correlations of seismic attributes for gross thickness, net-pay thickness, porosity-feet and hydrocarbon-feet. Figures VII-6, VII-7, and VII-8 demonstrate the prediction of these reservoir attributes. Maps such as these can be used to directly estimate oil-in-place and its distribution across the field. These maps resulted in good agreement with the understanding of the reservoir from both geological and engineering perspectives. Calculation of original-oil-in-place (OOIP) from the hydrocarbon-feet map results in 6,900,000 stock-tank barrels (stb) inside the Sooner Unit boundary. This value for OOIP is slightly larger than was initially estimated by the unitization technical committee in 1988 at $5,800,000 \mathrm{stb}$. While it is comforting to be able to calculate a reservoir volume and OOIP that is in good agreement with the well data, it is more important to compare the distribution of OOIP. Comparison between the pre-unitization interpretation of net pay from $\log$ data shown in Figure VII $\rightarrow$ with the seismic-attribute net-pay map in Figure VII-7 indicates that the location of many of the regularly spaced wells are not optimal. The series of seismic attributes used for correlation with petrophysical attributes include the following:

1) COMBINATION AMPLITUDE (absolute difference of maximum D Sand peakamplitude and Huntsman trough-amplitude),

2) D SANDSTONE ISOCHRON (measured for the D Sandstone peak to the Huntsman Shale trough),

3) D SANDSTONE ZERO-CROSSING ISOCHRON (measured from the $t+$ zerocrossing above the D Sandstone peak to the $+/$-zero-crossing below the D Sandstone peak),

4) D SANDSTONE TO J SANDSTONE ISOCHRON (measured from the D Sandstone peak to the J Sandstone peak),

5) D SANDSTONE INSTANTANEOUS FREQUENCY,

6) HUNTSMAN INSTANTANEOUS FREQUENCY,

7) D SANDSTONE INSTANTANEOUS PHASE,

8) HUNTSMAN INSTANTANEOUS PHASE,

9) D SANDSTONE HILBERT REFLECTIVITY, and

10) HUNTSMAN HILBERT REFLECTIVITY.

These 10 seismic attributes were measured at 36 well locations within the 3D survey and then compared to reservoir properties from well logs by multiple linear regression analysis. The statistical and multiple regression analyses which allowed creation of correlation equations were performed with the PC software program WinStat ${ }^{\mathrm{TM}}$. Coefficients from multiple linear regression are shown in Table VII-2.

The gross D Sandstone isolith is measured from the top of the D Sandstone where the shallow resistivity is greater than $10 \mathrm{ohm}$-meters to the erosional contact at the Huntsman Shale where the shallow resistivity is less than $5 \mathrm{ohm}$-meters. The net pay thickness is based on density porosity greater than 6 percent, shale volume of less than 30 percent and water saturation of less than 70 percent. Hydrocarbon porosity feet is calculated using conventional Archie equations for sandstones and previously described cut-off parameters. Results of multiple linear-regression analyses are as follows:

$\mathrm{Y}=\mathrm{X}_{1} \mathrm{C}_{1}+\mathrm{X}_{2} \mathrm{C}_{2}+\mathrm{X}_{3} \mathrm{C}_{3}+\mathrm{X}_{4} \mathrm{C}_{4}+\mathrm{X}_{5} \mathrm{C}_{5}+\mathrm{X}_{6} \mathrm{C}_{6}+\mathrm{X}_{7} \mathrm{C}_{7}+\mathrm{X}_{8} \mathrm{C}_{8}+\mathrm{X}_{9} \mathrm{C}_{9}+\mathrm{X}_{10} \mathrm{C}_{10}+\mathrm{Z}$ 
Where:

$\mathrm{Y}=$ reservoir attribute: gross, net or hydrocarbon-porosity thickness (ft)

$\mathrm{X}=$ Seismic attribute: amplitude, isochron, instantaneous frequency, etc.

$\mathrm{C}=$ Attribute coefficient from regression analysis

$\mathrm{Z}=$ constant

Results from the multiple linear regression analysis vary by reservoir property. The best correlation exists between 3D seismic attributes and the D Sandstone gross thickness with a correlation coefficient of 85 percent. As a result, there exists a 85 percent probability of predicting gross D Sandstone thickness with a standard error of $8.3 \mathrm{ft}$ from the 3D seismic data. Linear regression of the well $\log$ calculated versus 3D seismic predicted values for gross thickness shows a 77 percent correlation. Cross-plotting of well $l o g$ calculated versus 3D seismic predicted net pay thickness shows a 68 percent correlation. The reservoir property with the greatest usefulness in reservoir management (hydrocarbon pore-foot thickness) exhibits the weakest correlation coefficient between log values and 3D seismic attributes. Seismic attributes allow for only a 49 percent probability of predicting with a standard error of $0.86 \mathrm{ft}$. Cross-plot comparison of well-1og calculated versus 3D seismic predicted values of hydrocarbon pore-foot thickness yields a correlation coefficient of only 52 percent. While the use of 3D seismic attributes in the prediction of gross D Sandstone isolith thickness is strong, similar prediction of hydrocarbon pore-foot thickness is weak. Unfortunately, the prediction of gross sand thickness does not guarantee economic development of hydrocarbon pore-foot thickness in a given wellbore. Comparison of calculated gross thickness and correlative hydrocarbon pore-foot thickness for all wells in the Sooner Unit shows a linear regression correlation of 68 percent. It is unknown if the poor predictability of hydrocarbon pore-foot thickness is unique to this 3D survey or a function of the depositional system. One possibility for the poor correlation is that the reservoir sandstone has an average porosity of 12 percent. The regression correlations provided in Table VII-2 are not offered as universal for the Denver Basin; it is the approach that is important. Each seismic survey should have different coefficients and correlations.

Summary and Conclusions

Mapping of seismic attributes from 3D surveys over D Sandstone reservoirs can produce images of complex reservoir heterogeneity. It appears from empirical observation that $25 \mathrm{ft}$ is the minimum gross thickness required to image variability in the D Sandstone at the recorded frequencies of the Sooner survey. The acquisition of 3D seismic does not result in an easy and immediate interpretation of D Sandstone reservoirs. There are many steps to a successful interpretation of the D Sandstone from a 3D seismic survey.

The first step is correlation of seismic events with lithology. It was found that a vertical seismic profile (VSP) is not necessary and synthetic seismograms from density and sonic logs can provide sufficient lithological control. The Plainview formation (approximately $350 \mathrm{ft}$ below the D Sandstone) produces a strong reflector below the D and J 
Sandstones and the inclusion of log data through the Plainview in synthetic seismograms should insure a correct tie of lithology to seismic events. Drilling an exploratory or development well through the Plainview for these data is concluded to be more useful and probably less expensive than a VSP survey. After successful correlation of seismic events and lithology, all seismic attributes of the D Sandstone and bounding lithologies should be measured.

Well logs in the 3D-seismic area should be digitized and carefully calculated for gross and net thickness, porosity thickness and hydrocarbon-feet. A matrix of seismic-attribute and well $\dashv$ g properties can be analyzed quickly by multiple linear regression with inexpensive statistical software such as WinStat ${ }^{\mathrm{TM}}$. If the 3D survey covers few existing wells, it is advisable to generate hypothetical synthetic seismograms from representative well-log data to cover the expected range of D Sandstone and adjacent lithological development. Seismic attributes from the synthetic seismograms can be also analyzed by regression analysis to identify which attributes should be most important. The correlation process should be performed step-wise fashion to identify the best three to five high-correlation attributes for each reservoir property. The correlation coefficients can be then used to quantify reservoir development.

The correlation coefficients are applied to each gridded attribute from the seismic survey. These altered grids are then summed together with the correlation constant to produce a grid file containing the desired reservoir property. The resulting grid file can be displayed as a map of thickness or porosity thickness, etc. Oil-in-place can be then calculated from these maps as would be done from contoured well-log data.

It is important to pay attention to correlation error. Drilling a location with a predicted thickness of $10 \mathrm{ft}$ when the error is also $10 \mathrm{ft}$ is not advisable; however, drilling a location with a predicted thickness of $20 \mathrm{ft}$ with the same error may be acceptable. With these attribute-correlation maps it is possible to rank and prioritize drilling locations for infill development or exploration. It is possible with patience and systematic analysis to not only produce maps representing stratigraphic variability but to also quantify (with an error range) reservoir development in terms of net feet and porosity feet. The current cost of 3D seismic and interpretation covering approximately $7.7 \mathrm{sq}$ miles at the Sooner Unit would be approximately $\$ 250,000$. This is approximately equal to the cost of one completed well.

\section{References}

Sonnenberg, Stephen A. 1987. "Tectonic, Sedimentary, and Seismic Models for the D Sandstone, Zenith Field Area, Denver Basin, Colorado," The American Association of Petroleum Geologists Bulletin, 45(11): 1366-1377 (November 1987). 
Table VII-1

Processing Flow Used for Sooner 3D Seismic Data

1. SEG-D Demultiplex

Process Sample Rate:
Process Record Length $\quad 4 \mathrm{sec}$

2. Geometry Assignment

3. Deconvolution

Surface Consistent

Operator Length: $\quad 200 \mathrm{msec}$

Gap: $\quad 2 \mathrm{msec}$

Whitening: $\quad 0.01 \%$

4. Spectral Whitening: $\quad 10-129 \mathrm{~Hz}$

5. Reflection Statics First Pass Miser

Window: $\quad 100-2000 \mathrm{msec}$

Maximum Shift: $24 \mathrm{sec}$

6. Reflection Statics Second Pass Miser

Window: $\quad 300-1600 \mathrm{msec}$

Maximum Shift: $\quad 36 \mathrm{sec}$

7. NMO and First Break Suppression First Miser Velocities

8. Stack

9. Migration 90\% of Velocities

10. Filter: $\quad 10-100 \mathrm{~Hz} 0.0 \mathrm{sec}$

$10-100 \mathrm{~Hz} 1.6 \mathrm{sec}$

$10-60 \mathrm{~Hz} 4.0 \mathrm{sec}$

11. FX Deconvolution

12. Spectral Whitening: $\quad 10-100 \mathrm{~Hz}$ 
Table VII-2

Correlation Coefficients of Seismic and Electrical Log Data from Regression Analysis

\begin{tabular}{llll}
\hline Seismic Attribute & $\begin{array}{l}\text { Gross Isolith } \\
\text { Thickness }\end{array}$ & $\begin{array}{l}\text { Net Productive } \\
\text { Thickness }\end{array}$ & $\begin{array}{l}\text { Hydrocarbon- } \\
\text { Porosity } \\
\text { Thickness }\end{array}$ \\
\hline 1 & $8.176 \mathrm{e}-04$ & $1.018 \mathrm{e}-03$ & $9.710 \mathrm{e}-05$ \\
2 & $-5.411 \mathrm{e}+00$ & $-1.558 \mathrm{e}+01$ & $-1.611 \mathrm{e}+00$ \\
3 & $-1.316 \mathrm{e}+01$ & $-1.633 \mathrm{e}+00$ & $-8.883 \mathrm{e}-03$ \\
4 & $-5.356 \mathrm{e}-01$ & $3.317 \mathrm{e}+00$ & $3.080 \mathrm{e}-01$ \\
5 & $-3.444 \mathrm{e}+00$ & $-2.099 \mathrm{e}+00$ & $1.717 \mathrm{e}-01$ \\
6 & $-1.535 \mathrm{e}+00$ & $-6.446 \mathrm{e}-01$ & $-5.333 \mathrm{e}-02$ \\
7 & $5.148 \mathrm{e}+01$ & $1.570 \mathrm{e}+01$ & $5.107 \mathrm{e}-02$ \\
8 & $-1.660 \mathrm{e}+00$ & $-1.638 \mathrm{e}+00$ & $-9.367 \mathrm{e}-03$ \\
9 & $1.647 \mathrm{e}+00$ & $-1.443 \mathrm{e}+00$ & $-1.922 \mathrm{e}-01$ \\
10 & $-2.122 \mathrm{e}+00$ & $6.096 \mathrm{e}-01$ & $3.661 \mathrm{e}+00$ \\
Constant & 502.93 & 254.13 & 21.78 \\
"R" & $84.87 \%$ & $65.40 \%$ & $48.71 \%$ \\
Standard error & $8.3 \mathrm{ft}$ & $8.2 \mathrm{ft}$ & $0.87 \mathrm{ft}$ \\
\hline
\end{tabular}




\title{
ADVANCED SECONDARY RECOVERY PROJECT FOR THE SOONER “D” SAND UNIT,
}

\author{
WELD COUNTY, COLORADO \\ COOPERATIVE AGREEMENT DE-FC22-93BC14954
}

\section{Reservoir Compartments in the D Sandstone}

Geological-geophysical characterizations of the D Sandstone at the Sooner Unit indicate that both regressive and transgressive depositions which were influenced by recurrent movement of pre-Cambrian faults. Regional mapping of D Sandstone reservoirs at a field scale in the Denver Basin indicates length-to-width ratios of 2.5 to 1 . Geostatistical evaluation of reservoir heterogeneity using variograms constructed with sandstone thickness from electrical logs in the Sooner Unit indicates a correlation trend of 2 to 1 at a scale of nearly one mile by one-half mile. The major axis is oriented normal to paleo dip. Interpretation of functional data such as pressure and injection response leads to the conclusion that functional reservoir compartments have a major axis of one-half mile and a minor axis of one-quarter mile. The orientation of these functional reservoir compartments is generally parallel to the axis of the eroded valley. It is noted that the ratio of major-minor axes and orientations are the same at all scales, while functional dimensions of reservoir compartment size are approximately half that which is estimated from variogram analysis from electrical log data (Fig. VIII-1). These observations indicate that appropriate well spacing would have higher density across the axis of valley fill systems. In the specific case at the Sooner Unit, it appears that wells should have been placed at approximately $1980 \mathrm{ft}$ along and at $990 \mathrm{ft}$ across the system axes (approximately 45 acre per well). This drilling strategy can only work if a relatively clear interpretation of the reservoir and depositional system exists at the time of discovery and prior to development drilling.

An interpretation of the Sooner Unit D Sandstone reservoir before unitization in 1988 is shown in Figure VIII-2. The initial well spacing at the Sooner Unit was 40 acres per well, which is typical for D Sandstone fields. The map is a net-pay thickness contoured in a conventional manner used frequently for equity participation for waterflood units. While this map (and similar maps) is useful for unitization parameters and division of equity, it does little to describe the depositional and functional heterogeneity of the reservoir. Consequently, the use of this type of reservoir interpretation for implementing a waterflood or enhanced recovery project can result in disappointing recovery.

During the initial stages of waterflooding at the Sooner Unit, production was curtailed during re-pressurization of the reservoir by producing wells only a few days each month. This provided opportunity for pressure surveys at the producing wells which measured a stabilized static pressure. It became readily apparent from these pressure surveys that the reservoir was not pressurizing evenly across the field. An interpretation of functional reservoir compartments from the pressure data, injection breakthrough and non-reservoir development is shown in Figure VIII-3. The functional reservoir compartments are depicted as a series of ellipses which show reservoir and drainage areas shared by wells. These reservoir compartments are not in all cases absolute permeability barriers. By 1995, it was determined that there were four single-well (40 acre) reservoir compartments.

Shape characteristics from electrical logs indicate several depositional styles in the Sooner Unit. These depositional styles and petrographical analysis of core data indicate a 
most likely depositional model would be valley-fill and estuarine. The establishment of a depositional model helped the interpretation of 3D seismic data. The initial seismic modeling studies indicated that the amplitude of the D Sandstone event would be the primary indicator of sandstone development. The D Sandstone is a seismic thin bed at the frequencies recorded at Sooner and produces a single wavelet at the event time which corresponds to the D Sandstone reservoir. After mapping the D Sandstone amplitude at the Sooner Unit, it became clear from even casual observation that there were many places of poor correlation between good reservoir development and amplitude response, although the amplitude defines the approximate limits of the valley fill or estuarine system.

Ten seismic attributes were picked from the D Sandstone and adjacent horizons. These include simple attributes (such as amplitude and isochrons) and more complex attributes (such as phase and frequency). The display of these attributes in map-view were visually inspected for features which appeared to depict erosional and sedimentary features which would be expected in a valley fill and estuarine environment. Maps of attributes which produced patterns and textures which fit the depositional model gave comfort to cold statistical correlations of attributes with petrophysical properties from electrical logs. A map of instantaneous frequency at the Huntsman shale temporal horizon (below the D Sandstone) is shown in Figure VIII-4. Maps such as this demonstrate the complexity and scale of depositional features in valley-fill reservoirs which cannot be mapped from well data at spacings of 40 acres $(1320 \mathrm{ft})$.

It is concluded from the studies performed at the Sooner Unit that some infill drilling is required for a successful waterflood in D Sandstone compartments where normal well spacing is 40 acres or greater. After reviewing the failed waterfloods in the area around the Sooner Unit, it is also concluded that the primary reasons for these failures were small reservoir compartments and inadequate number of wells; especially injection wells. Reservoir interpretation using integrated 3D seismic data indicates that heterogeneity in valley fill reservoirs dictates drilling of wells with unconventional spacing and patterns for successful waterflood recovery.

\section{References}

Mossel, L.G. 1978. "Hydrocarbon Accumulations in the ‘D' Sand, Adams and Arapahoe Counties, Colorado," (1978 Symposium, Rocky Mountain Association of Geologists, Denver): $75-80$. 


\title{
ADVANCED SECONDARY RECOVERY PROJECT FOR THE SOONER “D” SAND
} UNIT,

\author{
WELD COUNTY, COLORADO \\ COOPERATIVE AGREEMENT DE-FC22-93BC14954
}

Reservoir Simulation for Waterflooding

Introduction

Using computer simulation to evaluate waterflood performance in a heterogeneous and compartmented reservoir can be a difficult task. Most small companies do not have the resources for sophisticated reservoir simulation nor is it economically justified in small reservoirs. Streamtube models for waterflood performance can provide a quick and effective evaluation of many elements expected from reservoir simulation. Simulations of individualwell and composite-well production data with streamtube models were successfully employed in the Sooner Unit project. Reservoir simulations using core, fluid and relative permeability data from the Sooner Unit reservoir indicate that waterflooding the D Sandstone could incrementally recover 24 percent of the original-oil-in-place (OOIP) in fully swept reservoir regions. Simulation studies indicate that as of October 1992, between 8 to 12 additional wells would be required to fully develop the waterflood at the Sooner Unit.

Reservoir simulation is a tool which can be an effective means of reservoir description and prediction of future performance. Reservoir simulation at the Sooner "D" Sand Unit (Sooner Unit) was performed with the following objectives:
1) Determine appropriate reservoir parameters for evaluation by computer simulation,
2) determine contacted (swept) oil by well,
3) predict ultimate recovery by well,
4) calculate un-swept reservoir volume, and
5) estimate number of wells required to fully develop secondary reserves.

Type of Simulation Model

The pressure-production performance of the 1440-acre Sooner Unit indicates more than eight functional reservoir compartments (Fig. IX-1). Imaging of the reservoir through 3D seismic, indicates many more potential reservoir compartments (Fig. IX-2). There are three major vertical units in the D Sandstone reservoir and each of these vertical reservoir units are sometimes difficult to correlate laterally. This poses a challenge for deterministic reservoir simulation. The reservoir must be divided into several layers with lateral changes and permeability barriers. There is the additional problem of imperfect production allocations during the primary-depletion phase. The iterations required to produce a realistic full-field model is staggering and then the model would be still non-unique and ambiguous. After some experimentation with finite-difference, three-phase, black-oil simulation; it was found that single-well and composite-well modeling with streamtube simulation software produced meaningful results in a time-efficient manner.

Two streamtube models were found to produce satisfactory results for evaluation by 
reservoir simulation of the Sooner Unit reservoir. These models should be also effective for other D Sandstone reservoirs. The first model is named $\mathrm{CO} 2$-Prophet. It was developed as part of the U.S. Department of Energy Class I Oil program under contract number DE-FC2293BC14960. The second model is named Polymer Predictive Model. Both models are free and available from the U.S. Department of Energy. These models generate streamlines for fluid flow between injection and production wells and then do displacement and recovery calculations along the streamtubes. The streamlines form flow boundaries for the streamtubes. A finite-difference routine is used for displacement calculations. Layers are created from a Dykstra-Parsons coefficient for description of permeability variation. CO2Prophet is a model for prediction by waterflood and enhanced recovery by $\mathrm{CO}_{2}$. The Polymer Predictive Model is a waterflood and polymer-enhanced waterflood model. Both models work well with the waterflooding-only option. CO2-Prophet has several options for injection patterns and the capability to construct custom, multiple-well patterns. The Polymer Predictive Model allows only a five-spot pattern but has better graphical capabilities. While these streamtube models have limitations, they also have advantages over more complex finite-difference models. These advantages are simplicity and speed. It is also recommended that they be used before attempting to construct a model with complex lateral permeability variations and multiple relative-permeability rock regions.

Useful core and relative permeability data were obtained from the Sooner Unit reservoir. Additionally, all well logs were digitized and the data were used for net-pay and water-saturation calculations. The average reservoir properties found at the Sooner Unit are as listed in the following table.

Table IX-1

Average reservoir fluid and rock properties from the Sooner Unit D Sandstone reservoir which were used for reservoir simulation

\begin{tabular}{lrlr}
\hline Depth & $6300 \mathrm{ft}$ & Gas Gravity & $1.0 \mathrm{Air}=1.0$ \\
Reservoir Temp. & $220^{\circ} \mathrm{F}$ & Solution Gas & $500 \mathrm{scf} / \mathrm{stb}$ \\
Net thickness & $17 \mathrm{ft}$ & Oil Viscosity & $0.48 \mathrm{cp}$ \\
Porosity & $12 \%$ & Oil Volume Factor & $1.365 \mathrm{rb} / \mathrm{stb}$ \\
Air Permeability & $21 \mathrm{md}$ & Water Salinity & $5000 \mathrm{TDS}$ \\
Dykstra-Parsons Coef. & 0.74 & Water Viscosity & $0.27 \mathrm{cp}$ \\
Oil Gravity & $42^{\circ}$ API & Water Volume & $1.04 \mathrm{rb} / \mathrm{stb}$ \\
\hline
\end{tabular}

History Matching

The parameters which are important for history matching with streamtube models are oil-in-place, oil saturation, Dykstra-Parsons coefficient of permeability variation, and oilwater relative permeability. An oil saturation of 65 percent at the start of the waterflood was used for simulations of Sooner Unit production performance. This represented a gas 
saturation of 17 percent at the end of primary. Conventional core analysis from the Sooner Unit and adjacent reservoirs indicated Dykstra-Parsons permeability variations from 0.7 to 0.8. Water-oil relative permeability studies on the Sooner Unit core indicated an irreducible water saturation of 19 percent and a residual oil saturation of 65 percent. The initial relative permeability to oil is 0.80 and the final relative permeability to water is 0.35 .

Relative permeability equations are used for constructing two-phase flow equations. An equation for the two-phase water relative permeability $\left(\mathrm{K}_{\mathrm{rw})}\right.$ is as follows with parameters from the Sooner Unit data shown in parentheses:

$$
K_{r w}=K_{w r o}\left[\frac{1-S_{w i r}}{1-S_{\text {orw }}-S_{\text {wir }}}\right]^{M}
$$

Where
$\mathrm{K}_{\mathrm{rW}} \quad$ relative permeability of water
$\mathrm{S}_{\mathrm{w}} \quad$ water saturation
M water equation exponent (2.5)
$\mathrm{S}_{\text {wir }} \quad$ irreducible water saturation $(0.19)$
$\mathrm{S}_{\text {orw }}$ residual oil to waterflood $(0.65)$
$\mathrm{K}_{\mathrm{wro}}$ endpoint relative permeability of water at residual oil saturation $(0.35)$

An equation for the two-phase oil relative permeability in the presence of water $\left(\mathrm{K}_{\text {row }}\right)$ is as follows:

$$
K_{\text {row }}=K_{\text {rocw }}\left[\frac{1-S_{w}-S_{\text {orw }}}{1-S_{\text {orw }}-S_{\text {wir }}}\right]^{N}
$$

Where

$\mathrm{K}_{\mathrm{ro}} \quad$ relative permeability of oil

$\mathrm{S}_{\mathrm{w}} \quad$ water saturation

$\mathrm{N} \quad$ oil equation exponent (2.5)

$\mathrm{S}_{\mathrm{wir}} \quad$ irreducible water saturation $(0.19)$

$\mathrm{S}_{\text {orw }}$ residual oil to waterflood $(0.65)$

$\mathrm{K}_{\text {rocw }}$ endpoint relative permeability of oil at irreducible water saturation $(0.80)$

Since injection patterns at the Sooner Unit are limited by the number of wells, narrow configuration of the reservoir and compartmented behavior, a two-spot injection pattern was concluded to be the best representation for history-matching and prediction by simulation. The expected recovery from a hypothetical 2 -spot, 40 -acre pattern was found to be 24 percent of OOIP to economical limits. Oil and total fluid rates were matched by varying the oil-inplace at the start of the waterflood and injection rates. An example of history-matching 
results for a single well is shown in Figure IX-3.

Table IX-2 summarizes results from single-well history-matching using a 2 -spot streamtube model. The average waterflood recovery of responding wells is about 78,000 bbl per well with a secondary recovery of 21 percent of the OOIP. This is equivalent to a secondary recovery of $115 \mathrm{bbl}$ ac-ft. Total recovery after primary and secondary is indicated to be 37 percent in efficiently swept areas. However, the summation of contacted oil-in-place by wells at the start of the waterflood is only 3,514 Mbbl.

Table IX-2

Listing of results from history matching of production performance

\begin{tabular}{rrrrr}
\hline Well & $\begin{array}{c}\text { Oil-In-Place at } \\
\text { Start of } \\
\text { Waterflood } \\
\text { (Mbbl) }\end{array}$ & $\begin{array}{c}\text { Model } \\
\text { Predicted } \\
\text { Secondary Oil } \\
\text { (Mbb1) }\end{array}$ & $\begin{array}{c}\text { Secondary } \\
\text { Recovery } \\
\text { Factor of OOIP }\end{array}$ & $\begin{array}{c}\text { Ratio of Pore- } \\
\text { Feet in Model } \\
\text { to Average in } \\
\text { 40 acre }\end{array}$ \\
\hline SU 13-16 & 212.8 & 48.5 & $12.9 \%$ & 0.71 \\
SU 14-16 & 89.0 & 9.9 & $2.6 \%$ & 0.29 \\
SU 1-21A & 195.1 & 35.5 & $9.4 \%$ & 0.65 \\
SU 2-21 & 354.7 & 89.0 & $23.7 \%$ & 1.18 \\
SU 4-21 & 230.5 & 63.3 & $16.8 \%$ & 0.88 \\
SU 6-21 & 266.0 & 73.8 & $19.6 \%$ & 1.18 \\
SU 7-21 & 354.7 & 101.4 & $27.0 \%$ & 1.32 \\
SU 9-21 & 399.0 & 92.9 & $24.7 \%$ & 0.65 \\
SU 15-21 & 195.1 & 58.3 & $15.5 \%$ & 1.53 \\
SU 21-16-9 & 461.0 & 137.8 & $36.7 \%$ & 0.59 \\
SU 2-28 & 177.3 & 46.7 & $12.4 \%$ & 1.92 \\
SU 7-28 & 579.1 & 172.8 & $46.0 \%$ & 0.97 \\
Total of Wells & 3514.3 & 929.9 & & 0.99 \\
Average of Wells & 292.9 & 77.5 & $20.6 \%$ & 0.44 \\
Standard Deviation & 133.6 & 43.2 & $11.5 \%$ & \\
\hline
\end{tabular}

This represents only 57 percent of the $6,200 \mathrm{Mbbl}$ oil-in-place at the start of waterflooding which was estimated from volumetric and primary production calculations. This is not surprising because four of the 19 wells at the start of waterflooding were not in communication with the rest of the reservoir.

In similar fashion to history-matching individual well performance by adjusting 
hydrocarbon pore-volume and injection rate, the composite performance of the Sooner Unit can be simulated. Table IX -3 shows the results from history matching the total Unit production history prior to the commencement of the project in October 1992. Examples of production and history-matching curves for the 2 -spot model listed in Table IX 3 is shown in Figure IX-4. Cumulative production prior to injection of water was $789 \mathrm{Mbbl}$. The total cumulative production (primary and secondary) from the Sooner Unit was 1,086 Mbbl on October 1992.

Table IX -3

Results from history matching the composite production from the Sooner Unit prior to October 1992

\begin{tabular}{rrrr}
\hline $\begin{array}{c}\text { Streamtube } \\
\text { Model }\end{array}$ & $\begin{array}{c}\text { Oil-In-Place at Start } \\
\text { of Waterflood } \\
(\mathrm{Mbbl})\end{array}$ & $\begin{array}{c}\text { Model Predicted } \\
\text { Secondary Oil } \\
(\mathrm{Mbbl})\end{array}$ & $\begin{array}{c}\text { Secondary Recovery } \\
\text { Factor of Volumetric } \\
\text { OOIP }\end{array}$ \\
\hline 5 Spot & 3287 & 825 & $12.0 \%$ \\
2 Spot & 4696 & 1086 & $16.0 \%$ \\
\hline
\end{tabular}

Table IX-2 shows that on October 1992, the pore-volume being swept as efficiently as a fully developed 5-spot waterflood contained only 3,287 Mbbl or 53 percent of the volumetric OOIP. Similarly, the less efficient 2 -spot waterflood model indicates a swept reservoir volume containing 4,696 Mbbl or 75 percent of the volumetric OOIP. Both models predict incremental waterflood recovery of nearly 2,000 Mbbl (2,789 Mbbl total primary and secondary) should be possible if all portions of the Sooner Unit reservoir were fully developed with at least one injector and one producer in each functional reservoir compartment.

The difference between total volumetric oil-in-place and oil-in-place being contacted and swept by waterflooding represents the undeveloped potential of the reservoir. Both the single-well and composite-well simulations indicate non-contacted or poorly contacted reservoir oil of over 3,000 $\mathrm{Mbbl}$ at the start of the project in 1992. Using reservoir conditions on October 1992, and results from 2-spot composite-well simulation there were probable, undeveloped reserves of $914 \mathrm{Mbbl}$ (2,000 Mbbl possible minus 1,086 Mbbl developed).

Having characterized the reserves and swept pore-volumes of effective waterflood producers, it is possible to quantify the number of wells which would be required to fully develop the waterflood and effectively sweep the entire reservoir. The average 40-acre recovery is indicated to be $78 \mathrm{Mbbl}(+/-44 \mathrm{Mbbl})$. Therefore, it would appear that 12 additional wells would be required to develop $914 \mathrm{Mbbl}$. This may be optimistic without clear imaging of reservoir compartment regions and boundaries. If 3D seismic can provide clear imaging of reservoir areas with thick net pay and compartment boundaries, it is possible that the expected reserves from targeted wells would be greater than the average of $78 \mathrm{Mbbl}$. Targeted wells could be expected to develop $122 \mathrm{Mbbl}$ per well where 3D seismic indicates net-pay thickness of greater than $15 \mathrm{ft}$. Using this reserve model for targeted wells, full development of the $914 \mathrm{Mbbl}$ might be achieved with as few as eight wells.

Simulation can also be used to quantify the economics of drilling locations and 
prioritize these locations by economic rank. A series of 40-acre, 2 -spot locations were simulated using the average Sooner Unit reservoir parameters and varying the net pay thickness. The economic value of these hypothetical locations was calculated using an oil price of $\$ 17.00 / \mathrm{bbl}$, net revenue interest of 82 percent, state taxes of 6 percent and lifting cost of $\$ 1,500$ per month. The total fluid rate in each 2 -spot pattern was fixed at $300 \mathrm{bbl}$ per day. Table IX-4 shows there is a linear relationship between cumulative income and net pay thickness. This table also should be useful as a template to screen other D Sandstone reservoirs for economical potential by waterflooding.

\section{Conclusion}

Reservoir simulations using core, fluid and relative permeability data from the Sooner Unit reservoir indicate that waterflooding the D Sandstone could incrementally recover 24 percent of the OOIP in fully swept reservoir regions. Using simple streamtube models, single-well and composite-well production data can be quickly history-matched to make estimates of swept reservoir volumes and probable undeveloped reserves. A development plan and economics can be prepared from expected reserves and the number of wells which would be required to exploit these undeveloped reserves.

Table IX-4

Economic Value of Various Net Thicknesses in a 40-acre, 2-Spot Waterflood Pattern Before Capital Expenditures

\begin{tabular}{rrrrr}
\hline \multirow{2}{*}{$\begin{array}{c}\text { Thickness } \\
\text { (feet) }\end{array}$} & $\begin{array}{c}\text { Economic Life } \\
\text { (years) }\end{array}$ & $\begin{array}{c}\text { Secondary } \\
\text { Recovery } \\
(\mathrm{Mbb1})\end{array}$ & $\begin{array}{c}\text { Cumulative } \\
\text { Income (M } \$)\end{array}$ & $\begin{array}{c}\text { Present Value } \\
(10 \% \text { pv M }\end{array}$ \\
\hline 5 & 5 & 27.3 & $\$ 269$ & $\$ 258$ \\
10 & 9 & 54.6 & $\$ 538$ & $\$ 490$ \\
15 & 13 & 80.5 & $\$ 807$ & $\$ 700$ \\
20 & 15 & 107.0 & $\$ 1,075$ & $\$ 891$ \\
25 & 18 & 129.5 & $\$ 1,337$ & $\$ 1,066$ \\
35 & 29 & 186.8 & $\$ 1,883$ & $\$ 1,383$ \\
\hline
\end{tabular}




\title{
ADVANCED SECONDARY RECOVERY PROJECT FOR THE SOONER “D” SAND UNIT,
}

\author{
WELD COUNTY, COLORADO \\ COOPERATIVE AGREEMENT DE-FC22-93BC14954
}

Targeted Infill Drilling and Economics

Introduction

Three wells were drilled by the project based on 3D seismic and integrated reservoir characterization study. One well was completed for water injection and two wells were completed as producers. The two production wells were contributing more than half (over 200 bopd) of the total production from the Unit at the end of the project in December 1995. Combination of seismic attributes proved successful for predicting reservoir development and locating infill targets. Horizontal drilling and completion from a cased hole was unsuccessful. A conventional vertical well was finally drilled at the proposed objective of the lateral completion. The locations of drilling activities are shown in Figure X-1.

Seismically Targeted SU $21-16-9$

Combinations of attribute-correlations were developed from empirical relationships between seismic attributes of the D Sandstone and adjacent lithology and petrophysical data from well logs. Correlations were developed for gross thickness, net-pay thickness and hydrocarbon-porosity feet. An example of attribute correlation for hydrocarbon-feet is shown in Figure X-2. These correlations predicted a net-pay thickness of $29+/-4 \mathrm{ft}$ for the SU $21-9$ 16 location. The actual net-pay thickness of the SU $21-16-9$ well is $26 \mathrm{ft}$ with above-average porosity development. Net-pay maps, based solely on electrical logs, predicted much thinner reservoir development at the location of the new well. The multiple-regression correlation technique appears to be valid and offers the ability to selectively target higher-density drilling locations with confidence for improved waterflood sweep. The SU 21-16-9 was completed with a stabilized oil rate of 220 bopd.

Horizontal Completion at the SU 10-21A

After assessing the reservoir compartments from engineering and geological data, there was a sense of dismay. There were as many as nine functional compartments that had been identified in the 1440 -acre unit. One proposed solution was to connect the compartments with horizontal completions from existing wells or new wells. The apparent advantages seemed compelling:

1) Effective use of existing infrastructure, such as roads, flowlines and power,

2) One well with laterals as effective as two vertical wells; and

3) Four ineffective, cased wellbores.

Functional reservoir compartments were identified from pressure and injection response data (Fig. X-3). It was decided to attempt a horizontal completion from the SU 10- 
21A water-injection well as it was not affecting waterflood response to the west or east 40acre offset wells (Fig. X-1 and Fig. X-3). The well had excellent injectivity and had ben injecting water at over 1000 bpd with no wellhead pressure. A radio-active and temperature survey indicated that water was being injected into the D Sandstone reservoir.

The drilling technology selected for the horizontal completion from the SU 10-21A well was developed by Amoco (Warren, et al 1993). The technology appeared to be inexpensive. This technology consists of a rotary-guided short-radius curve drilling system and the system can be used to drill drainholes with curvatures of approximately $30 \mathrm{ft}$ from existing wellbores. The curve-drilling assembly is composed of an anti-whirl poly-crystalline diamond bit, flexible joint, eccentric deflection sleeve, orientation indicator, and flexible drillstring. The drill string is turned at the surface with a power swivel. The articulated drill collars are lined with high-pressure hose to allow circulation through the bit. The casing is section-milled and a cement plug is set at the kick-off point. The system can drill to $90^{\circ}$ with a $30 \mathrm{ft}$ radius when conditions are ideal and achieve lateral reaches of $300 \mathrm{ft}$ or more. The use of lateral re-completions from injection wells was hoped to help contact un-swept oil and re-direct sweep in directions dictated by well spacing and geological heterogeneity. Two attempts were made with this technology to drill a lateral to the southwest from the SU 10$21 \mathrm{~A}$ well. The technology was unable to achieve a full $90^{\circ}$ curve or penetrate further than 30 $\mathrm{ft}$ beyond the casing.

This drilling system failed at the SU 10-21A for several reasons. The depth of operations for the D Sandstone is about $6300 \mathrm{ft}$. The weight on the razor-back knuckle joint and articulated drill collars is critical for proper drilling of the curve. A normal weight indicator is the only guide for the rig operator and provides inadequate control at a depth of $6300 \mathrm{ft}$ and corresponding string weight. At much shallower depths of $3500 \mathrm{ft}$ or less, there is much less string weight and the accuracy of the weight indicator is sufficient to properly load the bottom-hole drilling assembly. Trip time with a slick-line to check angle and orientation is slow. Frequent trips to check the bit and bottom-hole assembly limits effective time for drilling if operations are only working daylight tours.

After the failure of the USR lateral drilling, it was still believed important to determine if utilization of existing wells and infra-structure could be accomplished in the infill drilling and completion program. A more conventional mud motor with steering system and conventional drill rig were mobilized to the SU 10-21A well. A cement plug was placed in the wellbore across the casing window used for USR and a second $100 \mathrm{ft}$ section of casing was milled for the medium-radius lateral drilling. Again, two unsuccessful attempts were made to drill horizontally. Final displacement of the second lateral was $680 \mathrm{ft}(185 \mathrm{ft}$ south and $655 \mathrm{ft}$ west) at $6,239 \mathrm{ft}$ total-vertical-depth (TVD). The horizontal drilling was unsuccessful because the Graneros Shale overlying the D Sandstone was unstable and the horizontal hole collapsed during trips despite careful attention to mud properties and hydraulics. The Graneros Shale section is not a problem during conventional vertical drilling operations.

Despite the failure to complete a lateral extension from the SU 10-21A well, it was determined that a significant lithological or fault barrier exists at about $250 \mathrm{ft}$ west from the well. At a horizontal reach of 254 feet from the wellbore ( $94 \mathrm{ft}$ south and $236 \mathrm{ft}$ west with a TVD of $6239 \mathrm{ft}$ ), the mud motor stalled and drilling angle changed abruptly. This barrier is in agreement with distance-to-barrier calculations made from a pressure fall-off test performed on the well. The pressure transient behavior of this test indicates channel-like flow with a 
width of 400 to $500 \mathrm{ft}$. The 3D seismic also indicates a change west from the SU 10-21A well. The amplitude and isochron attributes of the D Sandstone waveform indicate rapid thickening of the section in the westerly direction.

Conclusions

The Sooner Unit D Sandstone reservoir has significant heterogeneity. Infill drilling to less than 40 acres per well is required to allow efficient waterflooding of certain portions of the reservoir. Vertical wells to the D Sandstone in the Denver Basin are relatively inexpensive and are quickly drilled with little mechanical risk. Targeting vertical wells using 3D seismic appears to offer the most efficient method to for infill drilling at low cost and with low risk.

Interpretation of functional data such as pressure and injection response leads to the conclusion that functional reservoir compartments have a major axis of one-half mile and a minor axis of one-quarter mile. The orientation of these functional reservoir compartments is generally parallel to the axis of the eroded valley in the Huntsman Shale. These observations indicate that appropriate well spacing should have higher density across the axis of valley-fill systems. In the specific case at the Sooner Unit, it appears that wells for primary development should have been placed at approximately $1980 \mathrm{ft}$ along and at $990 \mathrm{ft}$ across the system axes (approximately 45 acre per well). This drilling strategy can only work if a relatively clear interpretation of the reservoir and depositional system exists at the time of discovery and prior to development drilling. Experience from the Sooner Unit waterflood and other nearby D Sandstone waterfloods indicates that regular spacing of wells on 40 -acre patterns is inadequate for an efficient waterflood.

The experience from the Sooner Unit projects suggests that targeted drilling based on 1) a geological model, 2) understanding of functional reservoir compartments and 3) 3D seismic should be more efficient than blanket infill drilling. An economic comparison of targeted drilling and blanket infill drilling on 20 -acre patterns is shown in Table $\mathrm{X}-1$. This table is based on incremental cost and recovery and assumes that the waterflood infrastructure is already in place. The revenue calculations are based on an oil price of $\$ 17.00$ per bbl. This economic model suggests a $\$ 2,280,000$ advantage from targeted infill drilling in the best portions of the reservoir and effectively matching injection-production well pairs.

\section{References}

Warren, T.M., W. J. Winters and H.B. Mount, "Short-Radius Lateral Drilling System," Journal of Petroleum Technology, 45(2): 108-115 (February 1993). 
Table X-1

Economic Model for Comparison of Targeted and Blanket Infill Drilling

\begin{tabular}{lll}
\hline & Blanket Infill Drilling & Targeted Infill Drilling \\
\hline Number of Wells & 20 & 8 \\
Incremental Oil & $768,000 \mathrm{bbl}$ & $640,000 \mathrm{bbl}$ \\
& $11 \%$ of OOIP & $9 \%$ of OOIP \\
Capital Expenditures & $\$ 4,500,000$ & $\$ 1,800,000$ \\
Lease Operating Expense & $\$ 3,262,000$ & $\$ 1,902,000$ \\
Net Profit & $\$ 2,788,000$ & $\$ 5,068,000$ \\
\hline
\end{tabular}

Note: These numbers are incremental and assume the waterflood infrastructure is in place. 


\title{
ADVANCED SECONDARY RECOVERY PROJECT FOR THE SOONER “D” SAND UNIT,
}

\author{
WELD COUNTY, COLORADO \\ COOPERATIVE AGREEMENT DE-FC22-93BC14954
}

Summary and Conclusions

The project objective to improve recovery at the Sooner Unit was achieved. Projected recovery was increased from $1,556,000 \mathrm{bbl}$ to $1,861,000 \mathrm{bbl}$. Daily production from the Sooner Unit increased more than 100\% above the trend established before the project was initiated. A development plan was established to further increase total recovery to 2,252,000 bbl after the project term closed. Ultimate oil recovery from the D Sandstone reservoir is projected to be 32.6 percent of OOIP.

Several technologies were employed during the project. Successful elements of the project are 3D seismic imaging, selective infill drilling and reservoir management based on operational compartments, and reservoir description. The project acquired 3D seismic over a $7.7 \mathrm{sq}$-mile area. Transient and static pressure-test data were used with water-cut information for the delineation of operational compartments. Three vertical wells were drilled (one injector and two producers). Vertical drilling based on seismic-attribute maps proved effective while attempts at horizontal drilling and completion were unsuccessful. The greatest impact on describing the reservoir and developing an infill-drilling plan came from the 3D seismic. The greatest cost was incurred from horizontal drilling attempts.

Waterflood projects in the Cretaceous D Sandstone of the Denver-Julesburg Basin have been perceived as unattractive because of historically poor recovery. Reservoir heterogeneity and poor reservoir management practices are the major reasons for historically poor secondary recovery. The key to successfully developing a waterflood in the D sandstone is recognition of the depositional system and heterogeneity which is likely to have been created by that system. The waterflood must be designed to sweep oil from compartments and acknowledge anisotropy. Operators need to think in terms of non-standard well spacing and injection patterns to implement successful waterflood projects in the D Sandstone (and reservoirs with similar geological settings).

Results from the project demonstrate that waterflooding the D Sandstone can yield secondary oil equal to that obtained by primary depletion. The important concept for successful waterflooding the D Sandstone is injection by reservoir compartment and unconventional patterns. While infill drilling at 20 -acre spacing and developing the field on regular five-spot injection patterns would recover most of the moveable oil, it would not be economically efficient. Integrated reservoir characterization with 3D seismic can optimize infill locations with the minimum number of wells to maximize economic benefit.

Project studies concluded there were eight high-priority infill locations at the Sooner Unit. Three of these locations were drilled during the project. Work performed during the project increased production more than $100 \%$ and increased proved-developed and undeveloped reserves by $696,000 \mathrm{bbl}$. The Sooner Unit production rate was 400 bopd in October 1995, which is 220 bopd over the prior production trend. The current cost of the 3D seismic survey and three wells is $\$ 850,000$. The incremental proved-developed oil reserves resulting from just 3D seismic and three wells are placed at 305,000 bbl. The additional future income (using $\$ 17$ per bbl) before income taxes is calculated to be $\$ 1,233,000$ 
(undiscounted) and $\$ 876,000$ (discounted at $10 \%$ ). While the total project cost of $\$ 1,577,000$ is not expected to payout from the current incremental reserves, future development is expected to result in a 2 to 1 return. The project cost and remaining development expenditures are estimated to be $\$ 2,700,000$. Cash-flow and economic analysis of a $\$ 2,700,000$ expenditure for 696,000 bbl projected reserves indicates incremental income before income taxes of $\$ 2,854,000$ (undiscounted) and $\$ 1,901,000$ (discounted at $10 \%$ ). 